\title{
O MERCOSUL E O COMPROMISSO DEMOCRÁTICO
}

\author{
Mercosur and the democratic commitment
}

Carlos Alberto Moraes

Resumo: O Protocolo de Ushuaia sobre Compromisso Democrático no MERCOSUL, firmado em 1998, constitui-se em importante instrumento jurídico/político que visa assegurar o regime democrático entre os seus signatários, a saber, Argentina, Brasil, Paraguai, Uruguai, Venezuela, Bolívia e Chile. Não obstante o compromisso firmado, utilizando-se de técnica imposta pelo uso das chamadas "cláusulas democráticas", o texto do Protocolo de Ushuaia não se permitiu definir e caracterizar o que deve ser entendido por democracia. E assim, não sendo possível identificar quais os seus pressupostos ou elementos mínimos, torna-se possível a aplicação de severa penalidade, como no caso de suspensão do Estado Parte de integrar o bloco econômico, sem contar com uma referência segura para tanto. Em razão disto, buscar-se apontar essa insuficiência da cláusula democrática, demonstrando que a norma em questão é indeterminada e aberta, na medida em que permite considerável discricionariedade aos Estados Partes em sua aplicação, ocasionando grave insegurança jurídica entre os participantes. Assim, diante da indeterminação das chamadas "cláusulas democráticas" que tem por objetivo a manutenção do sistema político democrático nos Estados-Partes do MERCOSUL, abre-se a possibilidade de considerável discricionariedade na identificação dessa situação, ocasionando irresignação, instabilidade política e jurídica ao bloco. Além disto, toda essa liberdade para exegese do termo democracia permite um mero julgamento político, influenciado pelo clamor momentâneo que atravessam os Estados-Partes, possibilitando o uso estratégico da aplicação da cláusula democrática com base em interesses que desatinam ao objetivo principal do bloco. Nesse cenário, abordar-se-á os antecedentes do processo de integração econômica na América Latina até o surgimento do MERCOSUL, buscando-se identificar possíveis entraves na atualidade para a consolidação do bloco, a partir da observância de fatos históricos, políticos, econômicos e culturais referentes aos países participantes. Também será tradada qual a importância da democracia no que se refere à origem e à formação do MERCOSUL, enumerando-se os objetivos, além dos requisitos para ingresso e permanência dos Estados no bloco. Além disto, apresenta-se uma comparação entre o compromisso democrático no MERCOSUL e na União Europeia.

Palavras-chave: MERCOSUL. Cláusula democrática. Protocolo de Ushuaia. Indeterminação. Discricionariedade.

Artigo recebido em 28 jul. 2018 e aprovado em 26 ago. 2019. 


\begin{abstract}
The Ushuaia Protocol on Democratic Commitment in MERCOSUR, signed in 1998, is an important legal / political instrument aimed at ensuring democratic rule among its signatories, namely Argentina, Brazil, Paraguay, Uruguay, Venezuela, Bolivia and Chile. Despite the commitment made, using a technique imposed by the use of the so-called "democratic clauses", the text of the Ushuaia Protocol was not allowed to define and characterize what should be understood by democracy. And thus, if it is not possible to identify what its minimum assumptions or elements, it becomes possible to impose a severe penalty, as in the case of suspension of the State Party from integrating the economic bloc, without counting on a safe reference to do so. Because of this, we seek to point out this insufficiency of the democratic clause, demonstrating that the norm in question is undetermined and open, as it allows considerable discretion to the States Parties in its application, causing serious legal uncertainty among the participants. Thus, given the indeterminacy of the so-called "democratic clauses" aimed at maintaining the democratic political system in the MERCOSUR States Parties, the possibility of considerable discretion in the identification of this situation opens up, causing the bloc's political and legal instability. . In addition, all this freedom for exegesis of the term democracy, allows itself a mere political judgment, influenced by the momentary clamor that goes through the States Parties, allowing the strategic use of the application of the democratic clause based on interests that go beyond the main objective. of the block. In this scenario, the antecedents of the process of economic integration in Latin America will be approached until the emergence of MERCOSUR, seeking to identify possible current obstacles to the bloc's consolidation, from the observance of historical, political, economic and cultural facts related to the participating countries. It will also be translated the importance of democracy regarding the origin and formation of MERCOSUR, listing the objectives, as well as the requirements for the admission and permanence of states in the bloc. It also compares the democratic commitment in MERCOSUR and in the European Union.
\end{abstract}

Keywords: MERCOSUR. Democratic clause. Ushuaia Protocol. Indetermination. Discretion. 


\section{Introdução}

O presente estudo tem como objetivo a análise da discricionariedade que possuem os Estados Partes do Mercado Comum do Sul (MERCOSUL), a saber, Argentina, Brasil, Paraguai, Uruguai e Venezuela, na aplicação da chamada "cláusula democrática", presente no Protocolo de Ushuaia, sobre Compromisso Democrático entre MERCOSUL, Bolívia e Chile, que permite a suspensão do bloco daquele Estado Parte que a violar em seu sistema de governo democrático.

Em que pese o Protocolo de Ushuaia sobre Compromisso Democrático no MERCOSUL, de 1998, ser instrumento jurídico/político de considerável importância para formalizar e assegurar o compromisso democrático entre os seus signatários, o fato é que o texto do referido instrumento deixou de definir e caracterizar o que deve ser entendido como democracia, não se permitindo identificar quais os seus pressupostos ou elementos mínimos para a aplicação de uma grave sanção prevista em caso de seu descumprimento, que permite a suspensão do bloco do Estado Parte acusado de ruptura do compromisso democrático.

Em razão disto, buscar-se-á apontar essa insuficiência da cláusula democrática, demonstrando que a norma em questão é indeterminada e aberta, na medida em que permite considerável discricionariedade aos Estados Partes em sua aplicação, o que ocasiona grave insegurança jurídica entre os participantes.

O presente trabalho discorrerá sobre os antecedentes históricos do processo de integração econômica na América Latina, seus principais eventos e instrumentos firmados, até o surgimento do MERCOSUL. Além disso, adentrar-se-á sobre a importância do instituto da democracia para a origem e a formação do MERCOSUL. Ainda, será abordado o surgimento do MERCOSUL, apontando os seus objetivos e os requisitos para o ingresso e a permanência dos Estados participantes no bloco. Em seguida, o foco da análise serão as cláusulas democráticas na América Latina e as ratificações dos Protocolos do Ushuaia I e II. Finalmente, apresentar-se-á uma comparação entre o compromisso democrático estabelecido pelos países constituintes da União Europeia e do MERCOSUL. 


\section{MERCOSUL e o compromisso democrático}

Os compromissos democráticos servem como instrumento de observância do regime da liberdade, dos direitos humanos e dos direitos fundamentais, sendo utilizados nos tratados internacionais pela incursão de "cláusulas democráticas", que visam compromissar os Estados Partes à adoção, respeito, promoção e defesa da democracia. E, assim como em outros blocos, o MERCOSUL também está obrigado nesse compromisso, levando em conta que o reestabelecimento do regime democrático na América do Sul, foi o responsável pela viabilização de sua existência

\subsection{A evolução histórica dos processos de integração econômica na América Latina. Os antecedentes do MERCOSUL}

O processo de integração na América Latina remonta ao período de formação dos Estados-Nações na região, tendo estes como características em comum o subdesenvolvimento econômico e social.

O surgimento dos Estados Latinos está diretamente relacionado a dois processos indissociáveis, sendo o primeiro a internacionalização do modo de produção capitalista com caráter econômico e social, e, em segundo, o seu aspecto político-militar, que foi o processo de emancipação das colônias ibéricas ${ }^{1}$.

Historicamente, a possibilidade de compartilhamento e união de esforços entre os Estados na América Latina é muito bem vista em seu aspecto eminentemente político. Entretanto, as diferenças econômicas têm dificultado a integração no decorrer de décadas, principalmente devido à dependência dos mercados das grandes potências mundiais, que sempre defenderam irrestritamente os seus próprios interesses econômicos ${ }^{2}$.

Diante de tais obstáculos, o processo de integração Latino-Americana pode ser classificado didaticamente em quatro ondas ${ }^{3}$, conforme assevera Nilson Araújo de Souza, levando em conta as suas várias tentativas de

\footnotetext{
${ }^{1}$ WASSERMAN, Claudia. História da América Latina: cinco séculos (temas e problemas). 3. ed. Porto Alegre: Editora da UFRGS, 2010. p. 177.

${ }^{2}$ MACHADO, Luiz Toledo. A teoria da dependência na América Latina. Estudos Avançados, São Paulo, v. 13, n. 35, p. 199. 1999. Disponível em: http://www.scielo.br/pdf/ea/ v13n35/v13n35a18.pdf. Acesso em: 08 jul. 2018.

${ }^{3}$ SOUZA, Nilson Araújo de. América Latina: as ondas da Integração. Revista Oikos, Rio de Janeiro, v. 11, n. 1, p. 88, 2012. Disponível em: http://www.revistaoikos.org/seer/ Index.php/oikos/article/view/296/168. Acesso em: 08 jul. 2018
} 
consolidação, bem como as etapas percorridas em busca da concretização desse objetivo.

A primeira onda tem início na formação dos Estados-Nações na América Latina e vai até a grande crise mundial de 1914 a $1945^{4}$, quando várias tentativas de integração regional falharam no período 5 .

Nesse período, destaca-se o primeiro grande movimento integracionista latino-americano liderado por Simón Bolívar que, levando adiante os ideais integracionistas do venezuelano Francisco de Miranda, culminou na realização do Congresso Anfictiónico do Panamá, que ocorreu de 22 de junho a 15 de julho de 1826, na cidade do Panamá, na época em que fazia parte da Grande Colômbia ${ }^{6}$.

O Congresso Anfictiónico do Panamá contou com a presença da Grã-Colômbia (cujo território atualmente compreende Colômbia, Venezuela, Equador e Panamá), Peru, México e República Centro-Americana (que compreendia as atuais Guatemala, Honduras, Costa Rica, Nicarágua e El Salvador). Também participaram na condição de observadores os convidados Brasil, EUA - Estados Unidos, Grã-Bretanha e os Países Baixos ${ }^{7}$.

Segundo discorrem Figueiredo e $\mathrm{Braga}^{8}$, a matéria de fundo da idealização desse Congresso tinha como objetivo constituir uma instituição que unificasse, em algum nível, as repúblicas americanas que se tornaram independentes do Império Espanhol. Era consensual que o Congresso do ${ }^{4}$ ARTHMAR, Rogério. Os Estados Unidos e a economia mundial no pós-Primeira Guer-
ra. Estudos Históricos, Rio de Janeiro, n. 29, p. 104, 2002. Disponível em: http://biblio-
tecadigital.fgv.br/ ojs/index.php/reh/article/view/2156. Acesso em: 08 jul. 2018

${ }^{5}$ SOUZA, Nilson Araújo de. América LatIna: as ondas da Integração. Revista Oikos, Rio de Janeiro, v. 11, n. 1, p. 88, 2012. Disponível em: http://www.revistaoikos.org/seer/ Index.php /oikos/article/view/296/168. Acesso em: 08 jul. 2018.

${ }^{6}$ BUENO, Elen de Paula; OLIVEIRA, Victor Arruda Pereira de. O Congresso do Paraná (1826): perspectivas políticas, teóricas e jurídicas nas relações internacionais. Papel Político, [S.1.], v. 20, n. 1, p. 258, 2015. Disponível em: http://revistas.javeriana.edu.co/index. php/papelpol/article/view File/12632/10425. Acesso em: 08 jul. 2018.

${ }^{7}$ BUENO, Elen de Paula; OLIVEIRA, Victor Arruda Pereira de. O Congresso do Paraná (1826): perspectivas políticas, teóricas e jurídicas nas relações internacionais. Papel Político, [S.1.], v. 20, n. 1, p. 260, 2015. Disponível em: http://revistas.javeriana.edu.co/index. php/papelpol/ article/viewFile/ 12632/10425. Acesso em: 08 jul. 2018.

${ }^{8}$ FIGUEIREDO Alexandre Ganan de Brites; BRAGA, Márcio Bobik. Passagens. Revista Internacional de História Política e Cultura Jurídica, Rio de Janeiro. v. 9, n. 2, p. 313-314, maio/ago., 2017. Disponível em: http://www.revistapassagens.uff.br/index. php/Passagens/article/view/141/147. Acesso em: 08 jul. 2018.

Resenha Eleitoral (Florianópolis), v. 22, n. 1-2, p. 189-228, 2018 
Panamá constituiria uma aliança militar com o objetivo de defesa mútua, garantindo as independências recém-conquistadas e a manutenção das formas republicanas de governo.

$\mathrm{Na}$ oportunidade, foram celebrados quatro tratados, que propunham basicamente a integração da América Hispânica, sendo que o mais relevante deles foi o Tratado de União, Liga e Confederação de 1826, firmado por Colômbia, México, Peru e República Centro-americana. Esse tratado ainda é referenciado como emblemático para as iniciativas de integração na América Latina; contudo, nunca chegou a entrar em vigor, tendo em vista a ausência das ratificações ${ }^{9}$.

Após o Congresso do Panamá, novas tentativas de integração ocorreram (1831, 1838, 1839 e 1840), com a liderança do México, que convocou as nações latino-americanas para dar continuidade às conferências, que acabaram não ocorrendo por falta de interesse dos Estados ${ }^{10}$.

$\mathrm{O}$ andamento do movimento de integração somente foi retomado no final do ano de 1847, no Congresso de Lima, no Peru, quando os representantes dos Estados da Bolívia, Chile, Colômbia, Equador e Peru assinaram a Convenção Consular, Convenção de Correios, novo Tratado de União e Confederação, Tratado de Comércio e Navegação, mas também caíram no vazio, pois nenhum deles foi ratificado ${ }^{11}$.

Conforme expõe o autor Nilson Araújo de Souza ${ }^{12}$, ocorreu, na época, uma sucessão de outros tratados integracionistas, como foi o de 1856, quando, por iniciativa da Venezuela, foi firmado o Tratado Continen-

${ }^{9}$ FIGUEIREDO, Alexandre Ganan de Brites; BRAGA, Márcio Bobik. Passagens. Revista Internacional de História Política e Cultura Jurídica, Rio de Janeiro. v. 9, n. 2, p. 313, maio/ago. 2017. Disponível em: http://www.revistapassagens.uff.br/index.php/ Passagens/article/view/141/147. Acesso em: 08 jul. 2018.

10 SANTOS, Ricardo Soares Stersi dos. A integração latino-americana no século XIX: antecedentes históricos do Mercosul. Revista Seqüência, Florianópolis, n. 57, p. $177-$ 194, dez. 2008. Disponível em: https://periodicos.ufsc.br/index.php/sequencia/article/ view/14953. Acesso em: 08 jul. 2018.

11 SANTOS, Ricardo Soares Stersi dos. A integração latino-americana no século XIX: antecedentes históricos do Mercosul. Revista Seqüência, Florianópolis, n. 57, p. $177-$ 194, dez. 2008. Disponível em: https://periodicos.ufsc.br/index.php/sequencia/article/ view/14953. Acesso em: 08 jul. 2018.

12 SOUZA, Nilson Araújo de. América Latina: as ondas da Integração. Revista Oikos, Rio de Janeiro, v. 11, n. 1, p. 90, 2012. Disponível em: http://www.revistaoikos.org/seer/ Index.php/oikos/article/view/ 296/168. Acesso em: 08 jul. 2018. 
tal entre Chile, Peru, Equador, Bolívia, Costa Rica, Nicarágua, Honduras, México e Paraguai. No mesmo período, também foi acordado em Washington, por iniciativa da Guatemala, o Tratado de Aliança e Confederação entre Nova Granada, Guatemala, El Salvador, México, Peru, Costa Rica e Venezuela. Além disso, entre novembro de 1864 e março de 1865, por convite do governo peruano, com a participação da Colômbia, Chile, Venezuela, Equador, El Salvador e Peru, aprovaram-se quatro tratados, dentre eles o de União e Aliança defensiva.

Apesar de todo o esforço despendido, nenhuma dessas tentativas de integração logrou êxito. Existem inúmeras causas para esse fracasso, sendo fundamental a que prevaleceu nos primeiros cem anos de independência da América Latina, que foi a disputa entre Estados Unidos (EUA) e Inglaterra pela divisão da região em suas áreas de influência, ou mesmo, de domínio direto ${ }^{13}$.

As tentativas de integração na América Latina que transcenderam a nossa história estão diretamente relacionadas ao fenômeno da colonização ${ }^{14}$. Desde o encontro dos povos que habitavam a América com os Europeus, no século XV, luta-se pela completa independência, mas, até os dias atuais, isso não foi totalmente possível.

A independência política foi uma conquista histórica na formação dos Estados-Nações Latino-americanos, bem como as suas delimitações territoriais. Entretanto, a independência econômica tende a ser recalcitrante, refletindo na organização política, social e cultural dos países localizados abaixo da fronteira estadunidense ${ }^{15}$.

A autora Fernanda Frizzo Bragato, em estudo sobre a lógica da colonialidade e a violação seletiva de direitos humanos por meio da discriminação ${ }^{16}$, leciona:

${ }^{13}$ SOUZA, Nilson Araújo de. América Latina: as ondas da Integração. Revista Oikos, Rio de Janeiro, v. 11, n. 1, p. 90, 2012. Disponível em: http://www.revistaoikos.org/seer/ Index.php /oikos/article/ view/296/168. Acesso em: 08 jul. 2018.

${ }^{14}$ PORTO-GONÇALVES, Carlos Walter; QUENTAL, Pedro de Araújo. Colonialidade do poder e os desafios da integração regional na América Latina. Revista Latinoamericana Polis, [S.1.], n. 31, p. 8-9, 2012. Disponível em: http://journals.openedition.org/ polis/3749. Acesso em: 08 jul. 2018.

${ }^{15}$ WASSERMAN, Claudia. História da América Latina: cinco séculos (temas e problemas). 3. ed. Porto Alegre: Editora da UFRGS, 2010. p. 177.

${ }^{16}$ BRAGATO, Fernanda Frizzo. Discursos desumanizantes e violação seletiva de direitos humanos sob a lógica da colonialidade. Quaestio Iuris, Rio de Janeiro, v. 9, n. 4, p. 1812, 2016.

Resenha Eleitoral (Florianópolis), v. 22, n. 1-2, p. 189-228, 2018 
Continuamos a viver sob a mesma 'matriz de poder colonial'. Com a descolonização jurídico-política, saímos de um período de 'colonialismo global' para entrar num período de 'colonialidade global'. Embora as 'administrações coloniais' tenham sido quase todas erradicadas e grande parte da periferia se tenha organizado politicamente em Estados independentes, os povos não-europeus continuam a viver sob a rude exploração e dominação europeia/euroamericana. As antigas hierarquias coloniais, agrupadas na relação europeias versus não europeias, continuam arraigadas e enredadas na 'divisão internacional do trabalho’ e na acumulação do capital à escala mundial.

Por sua vez, o historiador Túlio Halperin Donghi, também sobre a colonialidade, descreve com maestria o processo de sucessão da dominação colonial ibérica pela dominação neocolonial dos novos centros de poder. No espaço que então era ocupado por Espanha e Portugal na América Latina, tradicionais colonizadores cederam o lugar para a entrada da Inglaterra e dos EUA, que disputavam entre si o domínio econômico da região ${ }^{17}$.

Os EUA, com elevada vocação imperialista para expandir seus territórios, após se sobreporem na América do Norte e Central, utilizando-se de poderio militar, se voltaram para a conquista de domínio sobre a América do Sul; contudo, aqui não se utilizaram da força bélica, mas sim de acordos comerciais como instrumento de dominação ${ }^{18}$.

Assim, em franca disputa com a Inglaterra pela hegemonia da região, os EUA apresentaram, em 1887, uma proposta para a realização de uma união aduaneira com o Brasil e, logo em seguida, no ano de 1889, avançaram na proposição de constituição de uma comunidade comercial direcionada a todos os Estados da América, o que seria uma ideia embrionária do que, no futuro, seria a chamada Área de Livre Comércio das Américas $(\text { ALCA })^{19}$.

${ }^{17}$ DONGHI, Túlio HalperIn. História da América Latina. Tradução de Carlos Nelson Coutinho. Rio de Janeiro: Paz e Terra. 1975. p. 149-200.

18 SOUZA, Nilson Araújo de. América Latina: as ondas da integração. Revista Oikos, Rio de Janeiro, v. 11, n. 1, p. 92, 2012. Disponível em: http://www.revistaoikos.org/seer/ Index.php/oikos/article/ view/296/168. Acesso em: 08 jul. 2018.

19 SOUZA, Nilson Araújo de. América Latina: as ondas da integração. Revista Oikos, Rio de Janeiro, v. 11, n. 1, p. 91, 2012. Disponível em: http://www.revistaoikos.org/seer/ Index.php/oikos/article/ view/296/168. Acesso em: 08 jul. 2018. 
Entre os anos de 1840 a 1870, a forte expansão industrial americana carecia de novos mercados, bem como necessitava conseguir mais fontes de matérias-primas para sua indústria, sempre com o resguardo de protecionismo e apoio estatal ${ }^{20}$. Nesse período, houve a aceleração do natural processo de concentração e centralização do capital, formando-se os grandes monopólios ${ }^{21}$.

Após esse período, ocorreu nos EUA uma fusão entre os monopólios industriais e os bancários, formando-se então o chamado capital financeiro e, a partir desse fato, a exportação de capital se sobrepõe ao comércio de produtos. Embasado nesse novo modelo, os estadunidenses decidem incorporar em seus domínios econômicos a América do Sul ${ }^{22}$.

Entretanto, os planos norte-americanos para a dominação sobre toda a América encontraria um grande obstáculo proporcionado por outro país tradicionalmente colonizador, a Inglaterra. Esse país, após mais de setenta anos em que ocorrera a chamada revolução industrial ${ }^{23}$, entre 1846 e 1849, foi considerado a oficina do mundo e, na direção oposta do forte protecionismo interno dos EUA, decidiu derrubar suas medidas protecionistas, propondo uma política de livre comércio ${ }^{24}$.

A investida inglesa foi refutada pelos países considerados mais desenvolvidos, como França, EUA, Alemanha, Japão, Itália e Rússia, que declinaram desse sistema de livre comércio. Entretanto, países sem condições de barganha, como, no caso, os localizados na América Latina, e na condição de subdesenvolvidos e pobres, acabaram aceitando a proposta inglesa ${ }^{25}$.

${ }^{20}$ HOBSBAWM, Eric J. A era do capital: 1848-1875. Tradução: Luciano Costa Neto. Rio de Janeiro: Paz e Terra, 2017. p. 300.

${ }^{21}$ SOUZA, Nilson Araújo de. América Latina: as ondas da Integração. Revista Oikos, Rio de Janeiro, v. 11, n. 1, p. 92, 2012. Disponível em: http://www.revistaoikos.org/seer/ Index.php /oikos/article/view/296/168. Acesso em: 08 jul. 2018.

22 SOUZA, Nilson Araújo de. América Latina: as ondas da Integração. Revista Oikos, Rio de Janeiro, v. 11, n. 1, p. 92, 2012. Disponível em: http://www.revistaoikos.org/seer/ Index.php /oikos/article/ view/296/168. Acesso em: 08 jul. 2018.

${ }^{23}$ HOBSBAWM, Eric J. A era das revoluções: 1789-1848. Tradução: Luciano Costa Neto. Rio de Janeiro: Paz e Terra. Cap. 2: A revolução industrial, p. 35-60.

${ }^{24}$ SOUZA, Nilson Araújo de. América Latina: as ondas da Integração. Revista Oikos, Rio de Janeiro, v. 11, n. 1, p. 93, 2012. Disponível em: http://www.revistaoikos.org/seer/ Index.php /oikos/article/ view/ 296/168. Acesso em: 08 jul. 2018.

${ }^{25}$ SOUZA, Nilson Araújo de. América Latina: as ondas da Integração. Revista Oikos, Rio de Janeiro, v. 11, n. 1, p. 93, 2012. Disponível em: http://www.revistaoikos.org/seer/ Index.php /oikos/article/ view/ 296/168. Acesso em: 08 jul. 2018

Resenha Eleitoral (Florianópolis), v. 22, n. 1-2, p. 189-228, 2018 
Com a implantação desse sistema, a Inglaterra participava com a produção e exportação de produtos industriais, cabendo aos países mais frágeis e que há pouco tempo haviam conseguido sua independência, a produção e exportação de produtos primários ${ }^{26}$.

Assim, no final do século XIX, houve na América do Sul o predomínio dos monopólios do capital financeiro e da exportação de capitais, ou seja, da imposição do chamado imperialismo, conforme denominado originalmente pelo economista inglês John A. Hobson ${ }^{27}$. Com base nesse domínio externo sobre a região, as possibilidades de integração Latino-americana foram consideravelmente enfraquecidas:

Hobson considera o fenômeno do imperialismo como um desajuste temporal e uma enfermidade curável do capitalismo da época. Todas as ideias expostas pelo autor neste trabalho envolvem sua teoria do excesso de poupança ou subconsumo, através da qual associa a expansão colonial com o desenvolvimento capitalista das metrópoles nos finais do século XIX. Não obstante, são sobretudo os fatores não econômicos que conduzem a política imperialista - aspectos políticos, ideológicos e morais.

Por outro lado, entre o período da chamada grande crise (19141945) até o início dos anos 1970 do século XX, iniciou-se a segunda "onda" de integração da América Latina, tendo como característica o processo de industrialização em vários Estados, principalmente Brasil, Argentina e México, mas também em outros países menores em dimensões territoriais, como Chile, Colômbia e Uruguai, quando se tornou possível produzir muito do que necessitavam importar das grandes potências ${ }^{28}$.

Com a eclosão da Grande Depressão a partir da crise de 1929 nos EUA, as economias Latino-americanas, cujo centro dinâmico é definido no centro capitalista demandante dos bens primários, sofreram fortemente

${ }^{26}$ SOUZA, Nilson Araújo de. América Latina: as ondas da Integração. Revista Oikos, Rio de Janeiro, v. 11, n. 1, p. 93, 2012. Disponível em: http://www.revistaoikos.org/seer/ Index.php /oikos/article/view/296/168. Acesso em: 08 jul. 2018.

${ }^{27}$ BUGIATO, Caio MartIns. Teoria do imperialismo: John Hobson. Revista de Iniciação Científica da FFC, Marília, v. 7, n. 2, p. 129, 2007.

${ }^{28}$ SOUZA, Nilson Araújo de. América Latina: as ondas da Integração. Revista Oikos, Rio de Janeiro, v. 11, n. 1, p. 94, 2012. Disponível em: http://www.revistaoikos.org/seer/ Index.php / oikos/article/view/296/168. Acesso em: 08 jul. 2018. 
seus reflexos. Com isso, principalmente as maiores economias, como Argentina, Brasil e México, se forçaram a desenvolver um Processo de Industrialização em substituição às importações ${ }^{29}$.

Essa nova fase econômica, derivada da industrialização nos países latinos, favoreceu a integração regional, aumentando o intercâmbio comercial entre eles. Ocorreu então, nesta fase, a primeira tentativa de integração entre Argentina e Brasil, países que, a partir da Conferência da Bacia do Prata, em 1941, assinaram vários acordos de integração comercial ${ }^{30}$, objetivando formar uma área de livre comércio, sendo esse um passo para a criação de uma união alfandegária que incluísse, além de Argentina e Brasil, os vizinhos Uruguai, Paraguai, Bolívia e Chile ${ }^{31}$.

Em 1942, com o objetivo de blindar o continente Latino-americano contra possíveis investidas nazi-facistas, os EUA prejudicaram a integração sul-americana em defesa de seus interesses, criando vários obstáculos comerciais, inclusive entre Brasil e Argentina, sendo esta última muito pressionada por haver se mantido neutra em respeito aos conflitos bélicos que ocorriam no mundo à época ${ }^{32}$.

A volta do movimento em prol da integração Latina só foi retomada em 1948, quando ocorreu a criação da Comissão Econômica para a América Latina (CEPAL) pela ONU, com o intuito de solucionar as demandas da região $0^{33}$.

${ }^{29}$ FERREIRA, Carlos Serrano. VIEIRA, Wilson. A construção da nação na América Latina, um processo Interrompido: bloqueios Internos e externos. PLURAL, Revista do Programa de Pós-Graduação em Sociologia da USP, São Paulo, v. 24.2, p. 54, 2017.

${ }^{30}$ VILELLA, Ana Maria. O Tratado da Bacia do Prata. R. Inf. legisl., Brasília, DF, ano 21 n. 81, jan./mar. 1984. Disponível em: https://www2.senado.leg.br/bdsf/bitstream/handle/id/186298/000406291. pdf? sequence=5. Acesso em: 08 jul. 2018.

${ }^{31}$ SOUZA, Nilson Araújo de. América Latina: as ondas da Integração. Revista Oikos, Rio de Janeiro, v. 11, n. 1, p. 96, 2012. Disponível em: http://www.revistaoikos.org/seer/ Index.php /oikos/article/view/ 296/168. Acesso em: 08 jul. 2018.

${ }^{32}$ SOUZA, Nilson Araújo de. América Latina: as ondas da Integração. Revista Oikos, Rio de Janeiro, v. 11, n. 1, p. 96, 2012. Disponível em: http://www.revistaoikos.org/seer/ Index.php /oikos/article/view/ 296/168. Acesso em: 08 jul. 2018

${ }^{33}$ HAJFNE, Jacqueline A. Hernández. A CEPAL e a integração regional latino-americana. Revista Análise Econômica, Porto Alegre, ano 20, n. 37, p. 108, mar. 2002. Disponível em: https://seer.ufrgs.br/AnaliseEconomica/article/view/10690/6317. Acesso em: 08 jul. 2018. 
Tendo a industrialização como meta para o desenvolvimento econômico da região, a CEPAL propôs um projeto de integração, tendo como base o incremento do mercado e a criação de grandes indústrias, principalmente aquelas que produziam bens de capital e bens intermediários, "criando um novo sistema para desenvolver o intercâmbio latino-americano, adequado a duas grandes exigências: a industrialização e a necessidade de atenuar a vulnerabilidade externa dos países da América Latina"34.

Em 1951, foi criado o Comitê de Cooperação Econômica do Istmo e a Organização dos Estados Centro-Americanos (ODECA), que, depois de várias transformações, passaria a chamar-se Mercado Comum Centro-americano (MCCA), em 1960, e o Sistema de Integração Centro-americano (SICA), na década de 1990. Entretanto, com a guerra entre El Salvador e Honduras, no ano de 1969, nova intervenção americana veio a prejudicar os movimentos integracionistas ${ }^{35}$.

Em 1952, o então Presidente argentino Juán Perón propôs ao representante do Brasil, Getúlio Vargas, o restabelecimento do Pacto A.B.C. entre Argentina, Brasil e Chile, que havia sido assinado no começo do século entre os três países. Contudo, com a mudança no executivo nos dois maiores países da América do Sul, um pela morte de Getúlio e outro pela queda de Perón, além de controvérsias e rivalidades partidárias internas nesses países, acabou sendo determinante para um novo fracasso integrativo ${ }^{36}$.

$\mathrm{Na}$ sequência, no ano de 1960, em Montevidéu, foi assinado o tratado que instituiu a Associação Latino-americana de Livre Comércio (ALALC), formada por Argentina, Brasil, Chile, México, Paraguai, Peru e Uruguai, considerado um avanço integracionista no século XX. Tỉnha como objetivo a ampliação do comércio regional. A ALALC propôs uma gradual queda das barreiras comerciais durante esse período. Contudo, por

${ }^{34}$ HAJFNE, Jacqueline A. Hernández. A CEPAL e a integração regional latino-americana. Revista Análise Econômica, Porto Alegre, ano 20, n. 37, p. 112, mar. 2002. Disponível em: https://seer.ufrgs.br/AnaliseEconomica/article/view/10690/6317. Acesso em: 08 jul. 2018.

35 SOUZA, Nilson Araújo de. América Latina: as ondas da Integração. Revista Oikos, Rio de Janeiro, v. 11, n. 1, p. 97, 2012. Disponível em: http://www.revistaoikos.org/seer/ Index.php /oikos/article/view/296/168. Acesso em: 08 jul. 2018.

${ }^{36}$ SANTOS, Raquel Paz dos. O impacto do projeto do pacto abc nas relações Brasil-Argentina durante o segundo governo Vargas. Revista OPSIS, Catalão, GO, v. 14, p. 54, 2014. n. Esp. Disponível em: https://revistas.ufg.br/Opsis/article/download/29893/18231. Acesso em: 08 jul. 2018. 
pressão norte-americana, com interesses contrários à integração latino-americana, os acordos foram mais modestos, limitando-se à área de livre comércio, que sequer chegou a se concluir. Além disso, a ALALC apresentou somente bons resultados durante aproximadamente três anos, sendo que as mudanças políticas diante da implantação das ditaduras militares na América do Sul colocaram um basta na continuidade da integração ${ }^{37}$.

Ainda sobre o fracasso da ALALC, é preciso registrar que, após a morte de John Kennedy, em 1963, e sob uma agenda agressiva de política externa norte-americana, passou a ser fundamental a substituição de governos latino-americanos que não estivessem de acordo com a abertura de suas economias para a entrada de capital estrangeiro. Sucederam-se, a partir daí, inúmeros golpes militares na região. E, como consequência, os novos governos instalados passaram a alinhar-se automaticamente à política do Departamento de Estado e a abrir caminho para a invasão econômica por parte das empresas transnacionais. Assim, como essa política e esse avanço econômico não interessava à efetivação da integração latino-americana, os acordos firmados para a criação da ALALC não avançaram ${ }^{38}$.

A terceira onda de integração latino-americana surgiu com novos atores, entre os anos 1960 e 1970, quando Japão e Alemanha aumentaram consideravelmente a produtividade do trabalho em detrimento dos EUA, abrindo a possibilidade de novas tentativas de integração na América Latina ${ }^{39}$.

Em 1969, foi firmado o Pacto Andino mediante o Acordo de Cartagena entre Bolívia, Chile, Colômbia e Peru, o qual contou com a posterior adesão da Venezuela, em 1973, constituindo-se num bloco com área de livre comércio ${ }^{40}$ :

${ }^{37}$ CAVLAK, Iuri. A Alalc como auge da integração sul-americana no século XX. História: debates e tendências, Passo Fundo, v. 12, n. 1, p. 38-48, jan./jun. 2012. Disponível em: http://seer.upf.br/ index.php/rhdt/ article/view/2708/1844. Acesso em: 08 jul. 2018.

${ }^{38}$ SOUZA, Nilson Araújo de. América Latina: as ondas da Integração. Revista Oikos, Rio de Janeiro, v. 11, n. 1, p. 101-102, 2012. Disponível em: http:/ /www.revistaoikos.org/seer/ Index.php /oikos/article/view/ 296/168. Acesso em: 08 jul. 2018.

${ }^{39}$ SOUZA, Nilson Araújo de. América Latina: as ondas da Integração. Revista Oikos, Rio de Janeiro, v. 11, n. 1, p. 102, 2012. Disponível em: http://www.revistaoikos.org/seer/ Index.php /oikos/article/view/ 296/ 168. Acesso em: 08 jul. 2018.

${ }^{40}$ SILVA, José Ultemar da. A importância da comunidade andina para a economia da América Latina. Revista Gerenciais, São Paulo, v. 5, n. 2, p. 72-82, 2006. Disponível em: https://www.redalyc.org/html/ 3312/331227108008/. Acesso em: 08 jul. 2018.

Resenha Eleitoral (Florianópolis), v. 22, n. 1-2, p. 189-228, 2018 
Objetiva promover o desenvolvimento balanceado e harmônico dos países-membros em condições de equilíbrio pela integração e pela cooperação econômica e social, acelerar o crescimento dos países andinos, gerar empregos e facilitar a participação no processo de integração regional, com o intuito de formar, gradualmente, um mercado comum latino-americano. Nesse sentido, a proposta é reduzir a vulnerabilidade externa dos países-membros e impor sua posição no contexto econômico internacional, reforçar a solidariedade regional e reduzir as diferenças no desenvolvimento que existem entre os países e, por fim, definir metas sociais orientadas para a melhoria da qualidade de vida dos diferentes grupos, com o fito de promover o desenvolvimento comum.

Apesar de ser um dos blocos mais antigos ainda vigentes na Latino-América, com o surgimento de vários outros, atualmente a CAN tem um papel limitado a resolver demandas conflituosas entre seus participantes, dado o ambiente de constante animosidade, que só cresceu nos últimos anos, culminando inclusive com a saída da Venezuela. Nessa esteira, são constantes as diferenças ideológicas entre alguns dos membros, as quais, somadas à falta de liderança em relação à integração econômica e política, têm limitado os objetivos práticos da existência do bloco ${ }^{41}$.

Em 1975, a proposta de criação do Sistema Econômico Latino-americano, o SELA - Sistema Económico Latinoamericano y del Caribe, que não era um bloco econômico regional, mas contribuía para a sua formação na medida em que propiciava ações coordenadas entre os vários governos da região, foi importante para demonstrar a força do projeto 'integracionista' latino-americano ${ }^{42}$.

A partir do esforço referido, em 1980, celebrou-se novo Tratado de Montevidéu, que transformou a ALALC na Associação Latino-americana de Integração (ALADI). Algumas mudanças significativas foram introduzidas, porém relativamente aos objetivos e aos mecanismos da Associação. Primeiramente, deixou-se de lado a intenção de instituir uma zona

${ }^{41}$ BRESSAN, Regiane Nitsch; LUCIANO, Bruno Theodoro. A comunidade andina no século XXI: entre bolivarianos e a Aliança do Pacífico. Revista de Sociologia e Política, Curitiba, v. 26, n. 65, p. 77, mar. 2018. Disponível em: http://www.scielo.br/pdf/rsocp/ v26n65/0104-4478-rsocp-26-65-0062.pdf. Acesso em: 08 jul. 2018.

${ }^{42}$ SOUZA, Nilson Araújo de. América Latina: as ondas da integração. Revista Oikos, Rio de Janeiro, v. 11, n. 1, p. 103, 2012. Disponível em: http:/ /www.revistaoikos.org/seer/ Index.php /oikos/article/view/ 296/168. Acesso em: 08 jul. 2018. 
de livre comércio, dando-se prioridade, a despeito do objetivo formal, à criação de um mercado comum e ao estabelecimento de uma zona de preferências tarifárias regionais, o que representa uma abdicação aos objetivos que antecederam a nova Associação, optando-se por uma integração mais simplificada ${ }^{43}$.

Os primeiros ensaios de aproximação entre Brasil e Argentina, na qualidade de principais personagens dessa trama política e econômica, datam do ano de 1985, quando ambos os países, em processo de redemocratização, firmaram a Declaração de Iguaçu, no contexto da superação da dinâmica de competição, fomentada pelos regimes militares, substituindo-a por um quadro de cooperação e convergências ${ }^{44}$.

A autora argentina Luciana Beatriz Scotti, por sua vez, retrata com riqueza de detalhes o processo de aproximação dos países que culminou com a assinatura do Tratado de Assunção e a então constituição do MERCOSUL $^{45}$ :

Finalmente, com o advento das democracias em ambos os países, na Argentina com a Presidência de Raúl Alfonsín em 1983 e no Brasil com o governo de José Sarney em 1985, o processo de integração em si foi seriamente enfrentado. Em 1985, os presidentes Sarney e Alfonsín assinaram a lei do Iguaçu, que resultou no ano seguinte ao programa de cooperação e integração econômica Brasil-Argentina (SPRUCE), ao abrigo do qual ambos os países chegaram a vários acordos setoriais. Seus objetivos, na época, eram inicialmente de natureza político-estratégica: fortalecer as democracias recentemente estabelecidas em ambos os países e eliminar qualquer hipótese de possível conflito. Apenas em segundo lugar foram impulsionados por interesses econômicos, especialmente: promover a cooperação e o intercâmbio tecnológico em determinadas áreas consideradas estratégicas: setor automotivo, bens de capital e alimentos. Posteriormente, assinaram a declaração conjunta de Iguazú sobre a política nuclear e uma acta em que foi criado um programa de integração e de

${ }^{43}$ SOUZA, Nilson Araújo de. América Latina: as ondas da integração. Revista Oikos, Rio de Janeiro, v. 11, n. 1, p. 104, 2012. Disponível em: http://www.revistaoikos.org/seer/ Index.php /oikos/article/view/296/168. Acesso em: 08 jul. 2018.

${ }^{44}$ ZANETTI, Augusto. O MERCOSUL: dimensões do processo de integração na América do Sul. São Paulo: Claridade, 2015. p. 29.

${ }^{45}$ SCOTTI, Luciana B. Derecho de la integración. 3. ed. Montevideo: Buenos Aires: Bdef 2018. p. 77.

Resenha Eleitoral (Florianópolis), v. 22, n. 1-2, p. 189-228, 2018 
cooperação económica gradual e flexível. No final de 1988, ambos os países realizaram o Tratado sobre integração, cooperação e desenvolvimento, no qual se comprometeram a formar um espaço económico integrado em dez anos, através da eliminação das barreiras pautais e não pautais e da liberalização de Comércio bilateral gradual. A vinda ao poder de dois presidentes com fortes orientações liberais, Carlos Menem na Argentina, em 1989, e Fernando Collor de Melo no Brasil em 1990, acelerou o processo integracionista. De fato, o período de rescisão do mercado comum em cinco anos foi reduzido, conforme estipulado na lei de Buenos Aires de 1990 de julho. Um novo passo foi a entrada do Uruguai e do Paraguai no programa de integração argentino-brasileira. Foi assim que chegamos à conclusão do Tratado de Assunção, em 26 de março de 1991, que criou o mercado comum do Sul, assinado e ratificado pelo Brasil, Uruguai, Paraguai e Argentina, e redobrar a aposta, porque o objetivo da zona de livre comércio foi abandonado e a substituição pela conformação de um mercado comum ${ }^{46}$.

${ }^{46}$ Texto original: Finalmente con la llegada de las democracias en ambos países, en Argentina con la presidencia de Raúl Alfonsín en 1983 y en Brasil con el gobierno de José Sarney en 1985, se encaró seriamente el proceso de Integración propiamente dicho. En 1985, los presidentes Sarney y Alfonsín firmaron el Acta de Iguazú, que dio lugar al año siguiente al Programa de Integración y Cooperación Económica Brasil-Argentina (PICE), bajo el cual ambos países llegaron a varios acuerdos sectoriales. Sus objetivos, por entonces, eran en primer ugar de carácter político-estratégico: fortalecer las democracias recientemente Instauradas en ambos países y eliminar toda hipótesis de conflicto posible. Sólo en un segundo lugar estaban movidos por Intereses económicos, en especial: promover la cooperación y el Intercambio tecnológico en ciertas áreas consideradas estratégicas: sector automotor, bienes de capital y alimentos. Posteriormente, firmaron la Declaración Conjunta de Iguazú sobre política nuclear y un acta en la que se estableció un programa de Integración y cooperación económica gradual y flexible. A fInales de 1988 ambos países celebraron el Tratado de Integración, Cooperación y Desarrollo, en el que se comprometieron a conformar un espacio económico Integrado en diez años, a través de la eliminación de las barreras tarifarias y no tarifarias y la liberalización gradual del comercio bilateral. La llegada al poder de dos presidentes con fuertes orientaciones liberales, Carlos Menem en Argentina en 1989 y Fernando Collor de Melo en Brasil en 1990, aceleró el proceso Integracionista. En efecto, se redujo el plazo para la terminación del mercado común em cinco años, según se estipuló en el Acta de Buenos Aires de Julio de 1990. Un nuevo paso fue la entrada de Uruguay y Paraguay en el programa de Integración argentIno- brasileño. Así es como llegamos a la celebración del Tratado de Asunción del 26 de marzo de 1991, que creó el Mercado Común del Sur, firmado y ratificado por Brasil, Uruguay, Paraguay y Argentina, y redoblando la apuesta, pues se abandonó la meta de la zona de libre comercio y se la reemplazó por la conformación de un mercado común (tradução nossa). SCOT'TI, Luciana

B. Derecho de la integración. 3. ed. Montevideo; Buenos Aires: Bdef, 2018. p. 77. 
Com isso, no dia 26 de março de 1991, os governos dos quatro países do Cone Sul: Argentina, Brasil, Paraguai e Uruguai, considerando a necessidade de ampliarem suas economias em prol do desenvolvimento econômico e social e o estreitamento das relações entre seus povos e, a fim de incrementar uma integração internacional mais autônoma e menos vulnerável às oscilações do mercado externo, procederam à assinatura do Tratado de Assunção. Esta iniciativa visava à constituição de um Mercado Comum, em linhas gerais, semelhante aos objetivos buscados pelo então Mercado Comum Europeu ${ }^{47}$.

Assim, uma vez constituído, o MERCOSUL assumiria as seguintes características, conforme o art. $1^{\circ}$ do Tratado de Assunção ${ }^{48}$ :

Livre circulação de bens, serviços e fatores produtivos mediante a eliminação das barreiras tarifárias ou de qualquer outra de efeito equivalente como as fitossanitárias e sanitárias e acusações de prática de dumping; - A implementação de uma política comercial comum em relação a terceiros Estados, através da criação de uma Tarifa Externa Comum (TEC); - A coordenação de políticas macroeconômicas objetivando harmonizar as relações comerciais entre os Estados membros no âmbito dos setores agrícola, industrial, fiscal, monetário, cambial, de capitais e comércio exterior entre outros; - O compromisso dos Estados membros com a busca da harmonização de suas legislações nas áreas pertinentes, visando o fortalecimento do processo de integração.

Segundo as lições de Luciane Klein e Alberto do Amaral Júnior, o MERCOSUL se enquadra dentro do que se conhece como "novo regionalismo", tendo como primeiros integrantes os Estados da Argentina, Brasil, Paraguai e Uruguai (Tratado de Assunção - 1991), contando com a incorporação da Venezuela como membro pleno a partir de 2012 e, atualmente, aguarda-se a ratificação do Protocolo de Adesão do Estado Plurinacional da Bolívia ao MERCOSUL. Contudo, em que pese a "falta de vigência do Protocolo, [...] na 48ª Reunião de Cúpula dos Chefes de Estado do MER-

\footnotetext{
${ }^{47}$ ZANETTI, Augusto. O MERCOSUL: dimensões do processo de integração na América do Sul. São Paulo: Claridade, 2015. p. 32.

48 ZANETTI, Augusto. O MERCOSUL: dimensões do processo de integração na América do Sul. São Paulo: Claridade, 2015. p. 33.
} 
COSUL, ocorrida em Brasília em 17.07.2015, oficializou-se formalmente o ingresso da Bolívia ao bloco"49.

\subsection{A importância da democracia na origem e na formação do MERCOSUL}

O termo democracia tem origem na Antiguidade Clássica, na Grécia, tendo em sua base estrutural a igualdade política, diretriz que era observada a ponto de variados cargos públicos terem sido preenchidos por meio de um sorteio, com o objetivo de proporcionar chances iguais a seus pretensos interessados. Já o processo eleitoral, por votação, era considerado um método oligárquico e, assim, contrário ao que se entendia por demo$\operatorname{cracia}^{50}$.

Contudo, no decorrer da história política, houve uma inversão na concepção dos valores democráticos ${ }^{51}$, estando esses cada vez mais vinculados a um governo representativo, enquanto a igualdade política fora lançada a um segundo plano, ocorrendo um distanciamento na efetiva participação popular nas atividades governamentais, reservada agora aos cuidados imediatos dos representantes eleitos. A alteração de paradigma conceitual do termo democracia é dinâmico no decorrer de todo o processo histórico, sendo que essa expressão já foi relacionada a inúmeros significados e combinações institucionais diversas, sendo compreendido de forma diferente, a depender do lugar ou da época em que foi utilizado ${ }^{52}$.

49 VIEIRA, Luciane Klein; JUNIOR AMARAL, Alberto do. A proteção internacional do consumidor no MERCOSUL. Revista de Direito do Consumidor, São Paulo, v. 106, p. 3, jul./ago. 2016. Disponível em: http://www.mpsp.mp.br/portal/page/portal/ documentacao_e_divulgacao/doc_biblioteca/ bibli_servicos_produtos/bibli_boletim/ bibli_bol_2006/RDCons_n.106.03.PDF. Acesso em: 20 jul. 2019.

${ }^{50}$ MEDEIROS, Nayara Fátima Macedo de. Democracia clássica e moderna: discussões sobre o conceito na teoria democrática. Revista Eletrônica de Ciência Política, Curitiba, v. 6, n. 2, p. 2, 2015. Disponível em: http://bibliotecadigital.tse.jus.br/xmlui/handle/ bdtse/2393. Acesso em: 20 jul. 2019.

51 A democracia direta da Antiga Grécia com o passar dos séculos, com o aumento das populações vai cedendo espaço para a democracia representativa ou Indireta, bem como a democracia participativa. MEDEIROS, Nayara Fátima Macedo de. Democracia clássica e moderna: discussões sobre o conceito na teoria democrática. Revista Eletrônica de Ciência Política, Curitiba, v. 6, n. 2, p. 1, 2015. Disponível em: http://bibliotecadigital. tse.jus.br/xmlui/handle/bdtse/2393. Acesso em: 20 jul. 2019.

52 MEDEIROS, Nayara Fátima Macedo de. Democracia clássica e moderna: discussões sobre o conceito na teoria democrática. Revista Eletrônica de Ciência Política, Curiti- 
Em que pese historicamente muitas vezes a dimensão vertical (representativa) ser considerada oposta à dimensão horizontal (participativa), como ocorreu na Grécia Antiga, hodiernamente, ambas são consideradas elementos essenciais na democracia, reconhecendo-se entre elas uma relação de complementariedade ${ }^{53}$.

No período da chamada guerra fria travada entre os EUA e a União Soviética, houve no contexto mundial um intenso processo de descolonização, sendo que a Revolução Cubana indicava que a América Latina poderia seguir no mesmo caminho, com a possibilidade de ocorrência de profundas alterações em sua ordem social ${ }^{54}$.

A partir de 1964, sentindo a possibilidade de sua vizinhança contaminar-se pela influência ideológica de seu opositor, os EUA orquestraram a proliferação de ditaduras no Cone Sul e, posteriormente, em quase toda a América Latina, que adotaram como referência a Doutrina de Segurança Nacional (DSN) ${ }^{55}$.

O Brasil foi o primeiro Estado a estabelecer uma ditadura civil-militar (1964-1985), dando início a uma onda de regimes cerceadores da participação política, como ocorreu na Argentina (1966 e novamente em 1976), no Chile (1973) e Uruguai (1976). Logo após esses, a quase totalidade dos países da região foi tomada por regimes autoritários, em maior ou menor grau, influenciados pela DSN, com exceção de Venezuela e México ${ }^{56}$.

Sem democracia no continente, a integração entre os Estados foi gravemente comprometida, pois os regimes autoritários, por variadas razões, apresentam dificuldade para patrocinar ou participar desse processo.

ba, v. 6, n. 2, p. 2, 2015. Disponível em: http://bibliotecadigital.tse.jus.br/xmlui/handle/ bdtse/2393. Acesso em: 20 jul. 2019.

${ }^{53}$ SARTORI, Giovanni. A teoria da democracia revisitada. São Paulo: Ática, 1994. p. 187

${ }^{54}$ MENDES, Ricardo Antonio Souza. Ditaduras civil-militares no Cone Sul e a doutrina de segurança nacional: algumas considerações sobre a historiografia. Revista Tempo e Argumento, Florianópolis, v. 5, n. 10, p. 8, jul./dez. 2013.

${ }_{55}$ MENDES, Ricardo Antonio Souza. Ditaduras civil-militares no Cone Sul e a doutrina de segurança nacional: algumas considerações sobre a historiografia. Revista Tempo e Argumento, Florianópolis, v. 5, n. 10, p. 8, jul./dez. 2013.

${ }^{56}$ MENDES, Ricardo Antonio Souza. Ditaduras civil-militares no Cone Sul e a doutrina de segurança nacional: algumas considerações sobre a historiografia. Revista Tempo e Argumento, Florianópolis, v. 5, n. 10, p. 9, jul./dez. 2013. 
Cabe destacar que os regimes ditatoriais possuem ideários nacionalistas, tendendo a buscar hegemonia e fomentar disputas geopolíticas com vizinhos, o que prejudica a multiplicação de práticas econômicas e de responsabilidades compartilhadas que são características da integração, que acabam, de certa forma, impondo processos de transferência de soberania política, ideia antipática aos olhos dos regimes que concentram poder em uma pessoa ou grupo, inspirando uma natural desconfiança em negociações multilaterais ${ }^{57}$.

Com o retorno da democratização na América do Sul, nos anos 1980, houve um cenário apropriado para o restabelecimento efetivo do processo de integração no continente, aparando antigas desconfianças, principalmente entre Brasil e Argentina ${ }^{58}$.

Segundo Adriano Freixo e Taís Ristoff, discorrendo sobre a relação da democratização e integração regional, a democracia passou a ser um pressuposto obrigatório para a integração regional ${ }^{59}$ :

O processo de integração regional se desenvolveu paralelamente ao processo de democratização de seus Estados-membros e o elemento 'democracia', ao menos no que se refere aos seus aspectos formais, passou a deter uma significativa importância nos discursos oficiais e foi considerado desde o início como um pressuposto para a integração.

Os dois governos de Brasil e Argentina, após a redemocratização, enfrentavam graves problemas econômicos ocasionados pelo peso da dívida contraída pelos militares e pela necessidade de conseguir créditos, que estavam cada vez mais escassos. Assim, a possibilidade de unir forças aparecia como excelente oportunidade para enfrentar os desafios da competição

\footnotetext{
${ }^{57}$ MARQUES, Fabrício R.; CREUZ, Luís Rodolfo Cruz e; DRIUSSO, Marcelo. O peso da redemocratização no processo de Integração entre Brasil e Argentina. Cadernos PROLAM/USP, São Paulo, ano 9, v. 2, p. 22, 2010

${ }^{58}$ MARQUES, Fabrício R.; CREUZ, Luís Rodolfo Cruz e; DRIUSSO, Marcelo. O peso da redemocratização no processo de Integração entre Brasil e Argentina. Cadernos PROLAM/USP, São Paulo, ano 9, v. 2, p. 43-44, 2010.

${ }^{59}$ FREIXO, Adriano; RISTOFF, Taís. Democracia e Integração regional: a experiência do MERCOSUL. Agenda Social (UENF), [S.1.], v. 1, p. 42, 2008 apud MARQUES, Fabrício R.; CREUZ, Luís Rodolfo Cruz e; DRIUSSO, Marcelo. O peso da redemocratização no processo de integração entre Brasil e Argentina. Cadernos PROLAM/USP, São Paulo, ano 9, v. 2, p. 31, 2010.
} 
econômica internacional, sendo que, juntos, tinham mais chance de superar a dependência externa e os dilemas do desenvolvimento ${ }^{60}$.

Nessa mesma linha, discorre Celso Amorim, reconhecendo a democracia como fator importante para a integração regional:

Na realidade, o grande impulso à aproximação Brasil-Argentina foi de natureza política. Quando os dois países saíam de governos militares, governos autoritários, eles perceberam que era preciso criar uma comunidade de interesses e que essa comunidade de interesses não poderia se esgotar nos contatos políticos. Era importante que essa comunidade de interesses também se lastreasse na parte econômica. Foi por isso que, no processo de aproximação Brasil-Argentina, se deu tanta ênfase ao aspecto comercial desde o primeiro momento. Estou me referindo ao ano de 1985, quando o Presidente Alfonsín - recentemente falecido, o que todos nós lamentamos e sentimos profundamente porque foi um grande democrata da região - e o Presidente Sarney - que não por coincidência nos representou nas homenagens após a morte do Presidente Alfonsín - iniciaram um processo de diálogo que teve várias vertentes ${ }^{61}$.

No que tange à aproximação do Uruguai com a Argentina e com o Brasil, esta já ocorria desde a década de 1970, tendo como principais referências o Convênio Argentino-Uruguaio de Cooperação Econômica, assinado em 20 de agosto de 1974, e o Protocolo de Expansão Comercial com o Brasil, assinado em 12 de junho de $1975^{62}$.

No final dos anos 1980, Argentina, Brasil e Uruguai já podiam comemorar o fim das ditaduras militares e o retorno dos governos civis, eleitos em processos democráticos. Entretanto, o mesmo não ocorria com o Paraguai, que ainda estava sob a égide de um governo de força, liderado pelo general Alfredo Stroessner ${ }^{63}$.

${ }^{60}$ MARQUES, Fabrício R.; CREUZ, Luís Rodolfo Cruz e; DRIUSSO, Marcelo. O peso da redemocratização no processo de Integração entre Brasil e Argentina. Cadernos PROLAM/USP, São Paulo, ano 9, v. 2, p. 43, 2010.

${ }^{61}$ AMORIM, Celso. A integração sul-americana. Diplomacia, Estratégia e Política, Brasília, DF, n. 10, p. 6, out./dez. 2009.

${ }^{62}$ TREIN, Franklin. MERCOSUL: uma breve análise de suas origens à crise atual. Civitas, Porto Alegre, ano 1, n. 1, p. 12, out. 2000.

${ }^{63}$ TREIN, Franklin. MERCOSUL: uma breve análise de suas origens à crise atual. Civitas, Porto Alegre, ano 1, n. 1, p. 12, out. 2000. 
Com sua queda em 3 de fevereiro de 1989, abriu-se caminho para o ingresso do quarto sócio do MERCOSUL, constituído em 1991, pela assinatura do Tratado de Assunção, entrando em vigor, na condição de uma associação entre Estados, no dia 29 de novembro do mesmo ano ${ }^{64}$.

Contudo, fica evidenciado que o reestabelecimento do processo democrático foi determinante para a formação do MERCOSUL, visto que a cooperação entre Estados que se unem a fim de possibilitar a melhoria das condições econômicas, sociais e políticas de sua população é favorecida nos governos democráticos em que as liberdades estão asseguradas por um Estado de Direito.

De outro lado, aponta-se que as ditaduras e autocracias são regimes que inviabilizam a efetiva formação de blocos de livre troca comercial, cultural e social, pois as relações de diálogo entre os agentes desse processo devem estar abertas, com base na transparência e liberdades civis, em que os atos do governo possam ser controlados pelo povo, que são os titulares do interesse público e, com o aumento de sua participação nas questões do Estado, refletirá no incremento do processo de integração regional.

A democracia é essencial para a redução das desconfianças e incertezas dos Estados em relação aos demais, facilitando suas relações econômicas, políticas e sociais, objetivadas pela integração regional. Além disso, estando acordada entre os integrantes do bloco regionalizado uma pauta de compromissos com a proteção dos direitos fundamentais, garantidos pelas Constituições nacionais dos Estados-membros, aumenta a pressão entre os países que, para permanecerem no bloco e usufruírem de suas vantagens, devem respeito aos direitos essenciais da pessoa humana, seja qual for a sua nacionalidade.

Além disso, seguindo as lições de Paulo Bonavides, a democracia se enquadra como um direito fundamental de quarta geração e, em sua concretização, reside o futuro da globalização política, a sua legitimidade como princípio e a força incorporadora de seus valores de libertação ${ }^{65}$. Para o destacado constitucionalista, "toda democracia, em geral, é paz e, de outro lado, toda ditadura ao revés é guerra" ${ }^{\prime 66}$.

${ }^{64}$ TREIN, Franklin. MERCOSUL: uma breve análise de suas origens à crise atual. Civitas, Porto Alegre, ano 1, n. 1, p. 12, out. 2000.

${ }^{65}$ BONAVIDES, Paulo. Curso de direito: direito constitucional. 15. ed. São Paulo: Malheiros, 2004. p. 572.

${ }^{66}$ BONAVIDES. Paulo. A quinta geração de direitos fundamentais. Revista Direitos Fundamentais \& Justiça, Belo Horizonte, n. 3, p. 93, abr./jul. 2008. 


\subsection{Os objetivos do bloco e os requisitos para entrada e permanência dos Estados participantes}

O MERCOSUL tem como meta a construção de um Mercado Comum entre os seus membros participantes e apresenta os seguintes objetivos, como já referido ${ }^{67}$ :

a) Eliminação das barreiras tarifárias e não-tarifárias no comércio entre os países membros; b) Adoção de uma Tarifa Externa Comum (TEC); c) Coordenação de políticas macroeconômicas; d) Livre comércio de serviços; e) Livre circulação de mão-de-obra; f) Livre circulação de capitais.

Os autores Florêncio e Araújo ${ }^{68}$ examinam cada um desses objetivos, iniciando pela eliminação de barreiras tarifárias e não tarifárias, sendo essa uma característica essencial do processo de integração, onde, desde 31 de dezembro de 1994, cada Estado-Parte poderá importar produtos de outro integrante da zona sem pagar tarifas. Essa vantagem recebe a denominação de Preferência Tarifária ou Margem em Preferência.

O segundo objetivo arrolado é a implantação da Tarifa Externa Comum, também concretizada em 31 de dezembro de 1994, prevendo que, quando da importação de algum produto proveniente de terceiro Estado, portanto fora do MERCOSUL, este ficará sujeito à mesma alíquota tarifária nos quatro países membros e, assim, somado com o objetivo anteriormente mencionado, contudo, em que pese ser de fundamental importância para o mercado comum, a União Aduaneira até o momento não está consolidada ${ }^{69}$.

A coordenação de políticas macroeconômicas, o terceiro objetivo do bloco, está relacionada ao controle em três esferas: política cambial (taxa de câmbio da moeda nacional em relação ao dólar ou a um padrão de referência externo), a política monetária (taxa de juros e quantidade de moeda a ser emitida) e a política fiscal (controle dos recursos a serem arrecadados e gastos pelo Estado). Esse controle permite, por exemplo, evitar

${ }^{67}$ FLORÊNCIO, Sérgio Abreu e Lima; ARAÚJO, Ernesto Henrique Fraga. MERCOSUL hoje. São Paulo: Alfa-Omega, 1998. p. 29.

${ }^{68}$ FLORÊNCIO, Sérgio Abreu e Lima; ARAÚJO, Ernesto Henrique Fraga. MERCOSUL hoje. São Paulo: Alfa-Omega, 1998. p. 29.

${ }^{69}$ FLORÊNCIO, Sérgio Abreu e Lima; ARAÚJO, Ernesto Henrique Fraga. MERCOSUL hoje. São Paulo: Alfa-Omega, 1998. p. 30.

Resenha Eleitoral (Florianópolis), v. 22, n. 1-2, p. 189-228, 2018 
desvalorização competitiva da moeda dos parceiros, contudo, o processo de implantação de sua efetividade é lento, pois implica limitação da soberania de cada país na condução de sua política econômica ${ }^{70}$.

Outro objetivo do bloco é a busca da liberação do comércio de serviços $^{71}$, ou seja, a prestação de serviços, que foi ganhando importância desde o tratado constitutivo do GAT'T, transformado posteriormente na OMC. Com isso, busca-se a eliminação das leis, normas e regulamentações nacionais que discriminem o fornecedor de serviços estrangeiro, a fim de garantir a livre circulação.

Diferente da livre circulação de serviços, outro objetivo do bloco é a livre circulação de trabalhadores entre os países integrantes do MERCOSUL, mas, para que isso seja possível, é necessária uma harmonização entre as legislações trabalhistas e previdenciárias dos participantes, bem como o envolvimento e a participação nesse processo de representantes dos empregadores e trabalhadores ${ }^{72}$.

Já a livre circulação de capitais conta com a participação de investidores dos países do bloco e tem o objetivo de facilitar os fluxos de capital; contudo, possíveis crises econômicas mundiais acabam por brecar o avanço desse movimento. Apesar do objetivo da liberação dos fluxos de capital, há uma tendência de maior controle do fluxo especulativo e, de outro lado, facilitar o fluxo de capitais produtivos ${ }^{73}$.

\subsection{As cláusulas democráticas e os Protocolos de Ushuaia I e II}

Com o fim da Segunda Guerra Mundial, ocorre uma mudança de paradigma nas relações internacionais que passam a construir novo ambiente de mútua cooperação e pela relativização do conceito de soberania,

${ }^{70}$ FLORÊNCIO, Sérgio Abreu e Lima; ARAÚJO, Ernesto Henrique Fraga. MERCOSUL hoje. São Paulo: Alfa-Omega, 1998. p. 30.

${ }^{71}$ Em 1997 foi firmado o Protocolo de Montevidéu sobre o Comércio de Serviços do MERCOSUL prevendo normas e princípios para o comércio de serviços entre os Estados Partes do MERCOSUL, com vistas a expansão do comércio em condições de transparência, equilíbrio e liberalização progressiva. PROTOCOLO de Montevidéu sobre o comércio de serviços do Mercosul. Buenos Aires, 1998. Disponível em: http://www.sgt4.mercosur. Int/es-es/Documents/Protocolo_de_Montevideo.pdf. Acesso em: 17 jul. 2018.

${ }^{72}$ FLORÊNCIO, Sérgio Abreu e Lima; ARAÚJO, Ernesto Henrique Fraga. MERCOSUL hoje. São Paulo: Alfa-Omega, 1998. p. 33.

${ }^{73}$ FLORÊNCIO, Sérgio Abreu e Lima; ARAÚJO, Ernesto Henrique Fraga. MERCOSUL hoje. São Paulo: Alfa-Omega, 1998. p. 33-34. 
destacando-se: a ascensão e a multiplicação das organizações internacionais, a intensificação dos processos regionais de integração política e econômica e a luta pela democracia, evidenciada pelo interesse e esforço comum da sociedade internacional na implantação e consolidação da democracia em diversos países e regiões do mundo ${ }^{74}$.

Com a criação da Organização das Nações Unidas (ONU, 1945) e a Declaração Universal dos Direitos Humanos (1948), houve uma grande ascensão da democracia e dos esforços internacionais pela implementação de regimes democráticos no mundo, consagrando a democracia como um ambiente fundamental para a proteção e realização efetiva dos direitos hu$\operatorname{manos}^{75}$.

Segundo a ONU, a democracia é um ideal reconhecido universalmente e um de seus valores fundamentais, valores estes que estão "incorporados na Declaração Universal dos Direitos Humanos e mais desenvolvidos no Pacto Internacional sobre os Direitos Civis e Políticos que consagra um conjunto de direitos políticos e liberdades civis que sustenta a democracia"76.

Hodiernamente, a maioria dos países no mundo são membros de, pelo menos, uma organização internacional, intensificando-se os processos de integração regional com a criação de blocos econômicos, ocasionando o surgimento das organizações de integração regional. No continente americano, há hoje inúmeras organizações internacionais de cooperação política e econômica, tais como a Organização dos Estados Americanos (OEA), a Comunidad de Estados Latinoamericanos y Caribeños (CELAC), a União das Nações Sul-americanas (UNASUL), a Alternativa Bolivariana para as

\footnotetext{
${ }^{74}$ PEREIRA, Luciano Meneguetti. A promoção e a proteção da democracia no continente americano: reflexões sobre as organizações de integração regional e as cláusulas democráticas. In: GOMES, Eduardo; XAVIER, Fernando César Costa; SQUEFF, Tatiana de A. F. Rodrigues Cardoso (org.). Golpes de Estado na América Latina e a cláusula democrática. Curitiba: Editora Instituto Memória, 2016. p. 89-90.

${ }^{75}$ PEREIRA, Luciano Meneguetti. A promoção e a proteção da democracia no continente americano: reflexões sobre as organizações de integração regional e as cláusulas democráticas. In: GOMES, Eduardo; XAVIER, Fernando César Costa; SQUEFF, Tatiana de A. F. Rodrigues Cardoso (org.). Golpes de Estado na América Latina e a cláusula democrática. Curitiba: Editora Instituto Memória, 2016. p. 91.

${ }^{76}$ PEREIRA, Luciano Meneguetti. A promoção e a proteção da democracia no continente americano: reflexões sobre as organizações de integração regional e as cláusulas democráticas. In: GOMES, Eduardo; XAVIER, Fernando César Costa; SQUEFF, Tatiana de A. F. Rodrigues Cardoso (org.). Golpes de Estado na América Latina e a cláusula democrática. Curitiba: Editora Instituto Memória, 2016. p. 99.
}

Resenha Eleitoral (Florianópolis), v. 22, n. 1-2, p. 189-228, 2018 
Américas (ALBA), o Acordo de Cooperação Energética (PETROCARI$\mathrm{BE})$, a Associação Latino-Americana de Integração (ALADI), o Sistema Económico Latinoamericano y del Caribe (SELA), a Organização dos Estados Centro- Americanos (ODECA), o Mercado Comum Centro-Americano (MCCA), a Mercado Comum e Comunidade do Caribe (CARICOM), a North American Free Trade Agreement (NAFTA) e o Mercado Comum do Sul (MERCOSUL), sendo uma característica comum entre a grande maioria dessas a exigência de regimes democráticos como condição para o ingresso, permanência e plena participação em seus órgãos e atividades

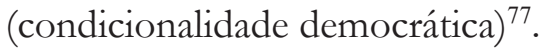

Com isso, a democracia perante os blocos é identificada como um princípio supremo, fundamental à estabilidade política, à paz e ao desenvolvimento dos países e dos processos de integração do continente americano, bem como para a proteção dos direitos humanos nas Américas. Nesse contexto é que surgem as chamadas cláusulas democráticas, pelo que destacamos sua presença em instrumentos jurídicos internacionais em três importantes organizações do continente americano: a OEA, o MERCOSUL e a UNASUL. Segundo Pereira, as cláusulas democráticas são definidas como $^{78}$ :

Um conjunto de normas (regras e princípios), previstas em tratados internacionais, que têm por finalidade obrigar os Estados Partes à adoção, respeito, promoção e defesa da democracia e dos direitos humanos fundamentais consagrados em tratados internacionais e em suas próprias Constituições, sob pena de lhes serem aplicadas sanções que importarão na supressão ou restrição dos direitos e prerrogativas que possuem no âmbito de seus respectivos espaços institucionais de integração regional.

77 PEREIRA, Luciano Meneguetti. A promoção e a proteção da democracia no Continente Americano: reflexões sobre as organizações de integração regional e as cláusulas democráticas. In: GOMES, Eduardo; XAVIER, Fernando César Costa; SQUEFF, Tatiana de A. F. Rodrigues Cardoso (org.). Golpes de Estado na América Latina e a cláusula democrática. Curitiba: Editora Instituto Memória, 2016. p. 99-100.

${ }^{78}$ PEREIRA, Luciano Meneguetti. A promoção e a proteção da democracia no Continente Americano: reflexões sobre as organizações de integração regional e as cláusulas democráticas. In: GOMES, Eduardo; XAVIER, Fernando César Costa; SQUEFF, Tatiana de A. F. Rodrigues Cardoso (org.). Golpes de Estado na América Latina e a cláusula democrática. Curitiba: Editora Instituto Memória, 2016. p. 112-113. 
A autora mexicana Ana Covarrubias Velasco discorre sobre a importância das cláusulas democráticas nas relações internacionais, enfatizando-as como instrumentos de pressão nos países destinados a promover a democracia, condicionando qualquer tipo de auxílio, ajuda e relações comerciais ao cumprimento de uma série de requisitos que definam o seu regime democrático ${ }^{79}$ :

A cláusula democrática é essencialmente entendida como a capacidade de um ou mais atores internacionais, sejam países ou instituições, para condicionar qualquer tipo de ajuda ou apoio, e até mesmo relações diplomáticas ou comerciais no caso de países, que o Estado receptor cumpre com uma série de requisitos que definem o seu regime como democrático. Esta cláusula é mais uma ferramenta para a promoção da democracia, sempre acompanhada pela proteção dos direitos humanos. Do ponto de vista extremo, sem sutilezas, é uma forma de pressão nas relações internacionais ${ }^{80}$.

Quanto à presença das cláusulas democráticas nos instrumentos jurídicos na América Latina, destaca-se o Protocolo de Reforma da Carta da Organização dos Estados Americanos (Protocolo de Washington), firmado em 1992, introduzindo na Carta da OEA um dispositivo sobre o tema (artigo 9ํ). A referida cláusula é aplicada em caso de eventuais Golpes de Estado nos países-membros da OEA, possibilitando a aplicação de penalidade de suspensão ao país sobre o exercício do direito de participação nas

${ }^{79}$ VELASCO, Ana Covarrubias. La cláusula democrática. Revista Mexicana de Política Exterior, [S.1.], n. 62-63, p. 63-77, nov./jun. 2000-2001. Disponível em: Https://Revistadigital.Sre.Gob.Mx/Images/Stories/ Numeros/ N62-63/Covarrubias.Pdf. Acesso em: 14 jul. 2018.

${ }^{80}$ Texto original: La cláusula democrática se entiende esencialmente como la facultad que tienen uno o varios actores Internacionales, ya sean países o Instituciones, para condicionar cualquier tipo de ayuda o apoyo, e Incluso relaciones diplomáticas o comerciales en el caso de los países, a que el Estado receptor cumpla con una serie de requisitos que defInan su régimen como democrático. Dicha cláusula es una herramienta más para la promoción de la democracia, siempre acompañada de la protección de los derechos humanos. Desde un punto de vista extremo, sIn sutilezas, se trata de una forma de presión en las relaciones Internacionales (tradução nossa). VELASCO, Ana Covarrubias. La cláusula democrática. Revista Mexicana de Política Exterior, [S.1.], n. 62-63, p. 63-77, nov./jun. 2000-2001. Disponível em: https://Revistadigital.Sre.Gob.Mx/Images/Stories/ Numeros/ N62-63/ Covarrubias.Pdf. Acesso em: 14 jul. 2018. 
sessões da Assembleia Geral, da Reunião de Consulta dos Conselhos da Organização e das Conferências Especializadas, e outras atividades ${ }^{81}$.

O Tratado Constitutivo da UNASUL ${ }^{82}$ foi assinado em 23 de maio de 2008, tendo como participantes Argentina, Brasil, Uruguai, Paraguai, Bolívia, Colômbia, Equador, Peru, Chile, Guiana, Suriname e Venezuela, sendo Panamá e México membros observadores, tendo como objetivo principal propiciar a integração entre os países da América do Sul. Em 26 de novembro de 2010, foi assinado o Protocolo Adicional ao Tratado Constitutivo da Unasul sobre Compromisso com a Democracia, com a previsão de que, havendo ameaça ou a concretização da ruptura da ordem democrática, violação da ordem constitucional, ou mesmo, que se ponha em risco o legítimo exercício do poder e a vigência dos valores e princípios democráticos (artigo $1^{\circ}$ ), podendo o violador sofrer desde suspensão até sanções políticas e diplomáticas dos outros participantes (artigo 4ª).

No ano posterior à assinatura do Tratado de Assunção, os presidentes dos Estados-Partes do MERCOSUL, reunidos na cidade de Las Leñas, na Argentina, assinaram, em 27 de junho de 1992, uma declaração (Declaração de Las Leñas), estipulando que a plena vigência das instituições democráticas seria condição indispensável para a existência e o desenvolvimento do MERCOSUL, assumindo a necessidade de estabelecimento de uma cláusula de garantia democrática ${ }^{83}$.

No ano de 1996, foi firmada, em São Luís (Argentina), a Declaração Política entre os Estados-Partes do MERCOSUL, criando Mecanismo de Consulta e Concertação Política (MCCP), objetivando se posicionar so-

${ }^{81}$ PEREIRA, Luciano Meneguetti. A promoção e a proteção da democracia no Continente Americano: reflexões sobre as organizações de integração regional e as cláusulas democráticas. In: GOMES, Eduardo; XAVIER, Fernando César Costa; SQUEFF, Tatiana de A. F. Rodrigues Cardoso (org.). Golpes de Estado na América Latina e a cláusula democrática. Curitiba: Editora Instituto Memória, 2016. p. 114-115.

82 PEREIRA, Luciano Meneguetti. A promoção e a proteção da democracia no Continente Americano: reflexões sobre as organizações de integração regional e as cláusulas democráticas. In: GOMES, Eduardo; XAVIER, Fernando César Costa; SQUEFF, Tatiana de A. F. Rodrigues Cardoso (org.). Golpes de Estado na América Latina e a cláusula democrática. Curitiba: Editora Instituto Memória, 2016. p. 119.

${ }^{83}$ SANT'ANNA, Sérgio Luiz Pinheiro. Democracia, crise política e os fundamentos da cláusula democrática. In: SCHEIDT, Eduardo; JUAN, Luis Gutierrez San; ARAÚJO, Elian. Integração na América Latina: a história, a economia e o direito. Jundiaí: Paco, 2014. v. 2, p. 20-21. 
bre questões internacionais de interesse comum. Na mesma oportunidade, foi firmada a Declaração Presidencial sobre Diálogo Político e Compromisso Democrático com o objetivo de reforçar o ambiente democrático e instituir o mecanismo de consulta, na hipótese de ruptura ou ameaça ao processo de integração ${ }^{84}$.

No âmbito do MERCOSUL, de forma a consolidar o conteúdo das Declarações anteriores, em 24 de julho de 1998, foi firmado o Protocolo de Ushuaia sobre Compromisso Democrático no MERCOSUL, Bolívia e Chile, tendo como participantes os Estados do Brasil, Argentina, Uruguai, Paraguai, Bolívia e Chile. Este tratado reafirma o compromisso democrático dos países da região e fixa que a plena vigência das instituições democráticas é condição essencial para o desenvolvimento dos processos de integração entre os Estados-Partes do MERCOSUL. Com isso, compreende-se que a existência e o funcionamento das instituições democráticas seriam elementos condicionantes do Estado Democrático de Direito ${ }^{85}$.

O Protocolo de Ushuaia é considerado a primeira grande norma jurídico-política desse processo de integração, ao regulamentar matéria de manutenção de compromisso democrático, expressando adesões formais ao Compromisso Democrático no MERCOSUL iniciado na Declaração Presidencial em San Luís, enquanto condição essencial para a continuidade do processo de integração no Cone Sul ${ }^{86}$.

A redemocratização, após longo período de ditaduras militares na América do Sul, foi essencial para que fosse viabilizada a união de forças que originaram o MERCOSUL, sendo que a cláusula democrática prevista no Protocolo de Ushuaia teve o objetivo de reforçar esse compromisso fundamental, visando preservar, nos países participantes, a manutenção do

${ }^{84}$ SANT'ANNA, Sérgio Luiz Pinheiro. Democracia, crise política e os fundamentos da cláusula democrática. In: SCHEIDT, Eduardo; JUAN, Luis Gutierrez San; ARAÚJO, Elian. Integração na América Latina: a história, a economia e o direito. Jundiaí: Paco, 2014. v. 2, p. 21.

${ }^{85}$ RIBEIRO NETO, Clarissa Correa; DIZ, Jamile BergamaschIne Mata. A situação do Paraguai no contexto do MERCOSUL: a integração sul-americana a partir de uma concepção democrática. In: DIREITO Internacional.1. ed. Florianópolis: FUNJAB/CONPEDI, 2014. p. 05.

${ }^{86}$ SANT'ANNA, Sérgio Luiz Pinheiro. Democracia, crise política e os fundamentos da cláusula democrática. In: SCHEIDT, Eduardo; JUAN, Luis Gutierrez San; ARAÚJO, Elian. Integração na América Latina: a história, a economia e o direito. Jundiaí: Paco, 2014. v. 2, p. 22. 
sistema democrático de governo que, sem dúvida, é o esteio dos objetivos e subsistência do bloco ${ }^{87}$.

O tratado assinado em Ushuaia reafirma os compromissos democráticos dos países integrantes do MERCOSUL, somados de Chile e Bolívia, materializando juridicamente essa pretensão conjunta, estabelecendo um texto normativo, estipulando obrigações e prevendo severas sanções para o caso de descumprimento.

No primeiro dispositivo do Protocolo, o elemento central da normativa indica que a vigência das instituições democráticas é condição essencial para o desenvolvimento dos processos de integração entre os países signatários, em que pese não haver elementos que indiquem as situações de fato e de direito que se consideram mantidas ou não à vigência das instituições democráticas, bem como qual a espécie de democracia que está se tratando e quando ela pode ser considerada violada (artigo $\left.1^{\circ}\right)^{88}$.

$\mathrm{Na}$ mesma esteira, o artigo $2^{\underline{o}}$ contém previsão de que se aplicará às relações que decorram dos respectivos Acordos de Integração, no caso de ruptura da ordem democrática em algum deles; entretanto, igualmente o artigo $1^{\circ}$ não descreve uma definição de democracia e ordem democrática ${ }^{89}$.

Os dispositivos subsequentes do Protocolo de Ushuaia, de forma simples e genérica, preveem a possibilidade de que, por consenso dos demais membros, após consulta ao Estado considerado violador das instituições democráticas, considerarão a natureza e o alcance das medidas a serem aplicadas, levando em conta a gravidade da situação existente, podendo aplicar a suspensão do direito de participar dos diferentes órgãos dos respectivos processos de integração até a suspensão dos direitos e obrigações resultantes desses processos ${ }^{90}$.

${ }^{87}$ MONTE, Deborah Silva do; ANASTASIA, Fátima. Cláusula democrática do Mercosul: indefinição conceitual e uso estratégico. Revista de Sociologia Política, Curitiba, v. 25, n. 62, p. 11, jun. 2017.

${ }^{88}$ BRASIL. Decreto no $\mathbf{4} .210$, de 24 de abril de 2002. Promulga o Protocolo de Ushuaia sobre Compromisso Democrático no Mercosul, Bolívia e Chile. Disponível em: http:/ /www. planalto. gov.br/ ccivil_03/decreto/2002/D4210.htm. Acesso em: 18 jul. 2018.

${ }^{89}$ BRASIL. Decreto no 4.210, de 24 de abril de 2002. Promulga o Protocolo de Ushuaia sobre Compromisso Democrático no Mercosul, Bolívia e Chile. Disponível em: http:/ /www. planalto. gov.br/ ccivil_03/decreto/2002/D4210.htm. Acesso em: 18 jul. 2018.

${ }^{90}$ BRASIL. Decreto no 4.210, de 24 de abril de 2002. Promulga o Protocolo de Ushuaia sobre Compromisso Democrático no Mercosul, Bolívia e Chile. Disponível em: http:// www.planalto. gov.br/ccivil_03/decreto/2002/D4210.htm. Acesso em: 18 jul. 2018. 
Em que pese se reconheça o avanço para o bloco do MERCOSUL e seus objetivos se firmarem em um tratado com dispositivos expressos sobre a necessidade de manutenção do sistema democrático, prevendo sanções para o descumprimento, é preciso reconhecer que a timidez conceitual e estrutural dos dispositivos que tratam do instituto da democracia poderá trazer mais prejuízos do que benefícios ao bloco, caso a cláusula democrática seja mal aplicada.

Por sua vez, o Protocolo de Montevidéu sobre Compromisso com a Democracia no MERCOSUL (Protocolo de Ushuaia II) foi firmado em 2011 pela Argentina, Brasil, Paraguai, Uruguai, Bolívia, Chile, Colômbia, Equador, Peru e Venezuela, constituindo-se num aperfeiçoamento de seu antecessor, prevendo sua incidência nos casos de ruptura ou ameaça de ruptura da ordem democrática, de uma violação da ordem constitucional ou de qualquer situação que ponha em risco o legítimo exercício do poder e a vigência dos valores e princípios democráticos (art. $\left.1^{\circ}\right)^{91}$.

Esse documento visa preencher um vácuo jurídico ${ }^{92}$ deixado pelas cláusulas abertas do Protocolo anterior, estabelecendo textualmente e de maneira exemplificativa as medidas que poderão ser tomadas em caso de ruptura ou ameaça de ruptura da ordem democrática do Estado-Parte.

Além da suspensão do direito de participação nos diferentes órgãos da estrutura institucional do MERCOSUL, houve no novo tratado a previsão da possibilidade de fechamento, de forma total ou parcial, das fronteiras terrestres, da suspensão ou limitação do comércio, do tráfego aéreo e marítimo, das comunicações e do fornecimento de energia, dos serviços e abastecimento ${ }^{93}$. Além disso, está prevista a possibilidade de pro-

${ }^{91}$ PEREIRA, Luciano Meneguetti. A promoção e a proteção da democracia no continente americano: reflexões sobre as organizações de integração regional e as cláusulas democráticas. In: GOMES, Eduardo; XAVIER, Fernando César Costa; SQUEFF, Tatiana de A. F. Rodrigues Cardoso (org.). Golpes de Estado na América Latina e a cláusula democrática. Curitiba: Editora Instituto Memória, 2016. p. 116.

92 PEREIRA, Luciano Meneguetti. A promoção e a proteção da democracia no continente americano: reflexões sobre as organizações de integração regional e as cláusulas democráticas. In: GOMES, Eduardo; XAVIER, Fernando César Costa; SQUEFF, Tatiana de A. F. Rodrigues Cardoso (org.). Golpes de Estado na América Latina e a cláusula democrática. Curitiba: Editora Instituto Memória, 2016. p. 118.

${ }^{93}$ PEREIRA, Luciano Meneguetti. A promoção e a proteção da democracia no continente americano: reflexões sobre as organizações de integração regional e as cláusulas democráticas. In: GOMES, Eduardo; XAVIER, Fernando César Costa; SQUEFF, Tatiana de A. F. 
mover a suspensão da Parte afetada no âmbito de outras organizações regionais e internacionais e adotar sanções políticas e diplomáticas adicionais (artigo $6^{\circ}$ ).

Apesar do Protocolo de Ushuaia II ser um avanço em relação ao primeiro, o mesmo ainda não teve sua vigência iniciada, devido à não ratificação de todos os Estados-partes supramencionados ${ }^{94}$.

Em que pese o conteúdo do texto do tratado deixar salvaguardar a proteção dos princípios inerentes à democracia e à plena vigência das instituições democráticas, não houve evolução do texto para sanar a indeterminação das cláusulas gerais do protocolo anterior. Assim, mantendo-se as cláusulas gerais, abre-se a possibilidade de interpretação discricionária do que seja um regime democrático, permitindo-se que, na aplicação da severa penalidade de suspensão de um Estado do bloco, possam esconder motivos de interesses dos mais diversos, muitas vezes azeitados pela dinâmica de políticas regionais, interesses econômicos individuais ou divergências ideológicas, principalmente quando há troca de governos na região ${ }^{95}$.

\subsection{O compromisso democrático na União Europeia e sua comparação com o MERCOSUL}

A Europa, desde que iniciou seu processo de integração, após a devastação do continente, ocasionada pela Segunda Guerra Mundial, sempre teve no compromisso democrático uma preocupação, principalmente se levar-se em conta que os seis países que inauguraram esse processo, Alemanha, Bélgica, França, Itália, Luxemburgo e Países Baixos, estavam arrasados economicamente após o imenso conflito bélico ${ }^{96}$.

Rodrigues Cardoso (org.). Golpes de Estado na América Latina e a cláusula democrática. Curitiba: Editora Instituto Memória, 2016. p. 118.

${ }^{94}$ PEREIRA, Luciano Meneguetti. A promoção e a proteção da democracia no continente americano: reflexões sobre as organizações de integração regional e as cláusulas democráticas. In: GOMES, Eduardo; XAVIER, Fernando César Costa; SQUEFF, Tatiana de A. F. Rodrigues Cardoso (org.). Golpes de Estado na América Latina e a cláusula democrática. Curitiba: Editora Instituto Memória, 2016. p. 118.

${ }^{95}$ RIBEIRO NETO, Clarissa Correa; DIZ, Jamile BergamaschIne Mata. A situação do Paraguai no contexto do MERCOSUL: a integração sul-americana a partir de uma concepção democrática. In: DIREITO internacional.1. ed. Florianópolis: FUNJAB/CONPEDI, 2014. ${ }^{96}$ CUNHA, Débora Coutinho; MARTINS, Fernanda de Castro Brandão. A União Europeia e a promoção do modelo liberal-democrático: a atuação no sul e leste da Europa e novos desafios. Revista de Estudos Internacionais, [S.1.], v. 8, p. 221, 2017. 
Assim, durante a década de 1950, havia grande interesse na construção de vínculos institucionais que promovessem, além da reconstrução dos países e de suas economias, uma estabilidade na região, apostando na manutenção de instituições democráticas como sistema de governo ${ }^{97}$.

Contudo, a previsão de cláusulas democráticas nos tratados entre os países interessados em aderir ao bloco econômico, bem como para a permanência no mesmo não ocorreu de uma vez só e, sim, foi sendo incluída gradualmente no decorrer do tempo ${ }^{98}$.

Somente a partir dos anos 1960, com o interesse na adesão no processo de integração da Grécia, Portugal e Espanha, houve uma preocupação mais evidente com a exigência acerca do respeito à democracia, já que esses países enfrentavam graves crises políticas e institucionais ${ }^{99}$.

Assim, apenas com a transição democrática, esses países puderam aceder às Comunidades, em um processo que se prolongou por quase duas décadas e se realizou com assistência do bloco. Como resultado, o Ato Único Europeu, assinado em 1986, incluiu, pela primeira vez, referências explícitas à democracia em seu Preâmbulo, afirmando a determinação dos países-membros em trabalhar para a promoção da democracia, com base nos direitos fundamentais reconhecidos em suas constituições ${ }^{100}$.

No ano de 1992, o Tratado de Maastricht, documento de criação da União Europeia, foi expresso no sentido de prever que o bloco estaria aberto à adesão de qualquer Estado europeu que respeitasse os princípios da liberdade, democracia, direitos humanos e liberdades fundamentais e o Estado de Direito. Após isso, os países que desejassem aderir ao bloco devem atender os critérios de Copenhagen, estabelecidos em 1993 pelo Conselho Europeu de Copenhagen e reforçados pelo Conselho Europeu

${ }^{97}$ CUNHA, Débora Coutinho; MARTINS, Fernanda de Castro Brandão. A União Europeia e a promoção do modelo liberal-democrático: a atuação no sul e leste da Europa e novos desafios. Revista de Estudos Internacionais, [S.1.], v. 8, p. 223, 2017.

${ }^{98}$ CUNHA, Débora Coutinho; MARTINS, Fernanda de Castro Brandão. A União Europeia e a promoção do modelo liberal-democrático: a atuação no sul e leste da Europa e novos desafios. Revista de Estudos Internacionais, [S.1.], v. 8, p. 224, 2017

${ }^{99}$ CUNHA, Débora Coutinho; MARTINS, Fernanda de Castro Brandão. A União Europeia e a promoção do modelo liberal-democrático: a atuação no sul e leste da Europa e novos desafios. Revista de Estudos Internacionais, [S.l.], v. 8, p. 224, 2017.

${ }^{100}$ CUNHA, Débora Coutinho; MARTINS, Fernanda de Castro Brandão. A União Europeia e a promoção do modelo liberal-democrático: a atuação no sul e leste da Europa e novos desafios. Revista de Estudos Internacionais, [S.1.], v. 8, p. 224, 2017.

Resenha Eleitoral (Florianópolis), v. 22, n. 1-2, p. 189-228, 2018 
de Madri, em 1995. Em 1997, o Tratado de Amsterdã complementou esse arcabouço normativo ao formalizar a cláusula democrática para o bloco da União Europeia ${ }^{101}$.

Por sua vez, o Tratado de Amsterdã contém a previsão de que a União Europeia se assenta nos princípios da liberdade, da democracia, do respeito pelos direitos do Homem e pelas liberdades fundamentais, bem como do Estado de direito, princípios que são comuns aos Estados-Membros. Além disto, expressa o seu compromisso com o desenvolvimento e o reforço da democracia e do Estado de direito, bem como com o respeito dos direitos humanos e das liberdades fundamentais ${ }^{102}$.

Finalmente, em 2009, foi aprovado o Tratado de Lisboa que, na mesma linha dos tratados anteriores firmados no âmbito da União Europeia, manteve-se firme nos propósitos democráticos do bloco, reforçando o compromisso com a manutenção de seus princípios fundamentais e respeito à democracia ${ }^{103}$.

Apesar da previsão de cláusula democrática, principalmente nos Tratados de Amsterdã e Lisboa, o fato é que, se compararmos com a cláusula democrática prevista para o MERCOSUL, no Protocolo de Ushuaia sobre Compromisso Democrático no MERCOSUL, Bolívia e Chile, ambas em pouco se diferem no sentido de também não haver uma definição do que seja democracia, permitindo igualmente que o país considerado violador do compromisso democrático possa sofrer suspensão em seus direitos e obrigações como Estado-Membro da União Europeia.

Assim, o presente trabalho se faz importante pela busca de se propor a estipulação de balizas caracterizadoras do compromisso democrático, definindo claramente os seus elementos, pressupostos e a sua extensão daquilo que se entenderá por democracia, possibilitando aos países signatários

${ }^{101}$ CUNHA, Débora Coutinho; MARTINS, Fernanda de Castro Brandão. A União Europeia e a promoção do modelo liberal-democrático: a atuação no sul e leste da Europa e novos desafios. Revista de Estudos Internacionais, [S.l.], v. 8, p. 224, 2017.

${ }^{102}$ UNIÃO EUROPEIA. Tratado de Amesterdão. Luxemburgo: Serviço das Publicações Oficiais das Comunidades Europeias, 1997. Disponível em: https://europa.eu/european-union/sites/europaeu/ files/docs/body/treaty_of_amsterdam_pt.pdf. Acesso em: 20 jul. 2018.

${ }^{103}$ ASSEMBLEIA DA REPÚBLICA. Tratado de Lisboa. Lisboa: Assembleia da República, mar. 2008. Disponível em: https://www.parlamento.pt/europa/Documents/Tratado_Versao_Consolidada.pdf. Acesso em: 20 jul. 2018. 
dos tratados que preveem cláusulas democráticas, no caso o Protocolo de Ushuaia, não serem surpreendidos com penalidades incorretas e injustas com base na discricionariedade de cláusulas gerais e indeterminadas, proporcionando um ambiente de desconfiança e desarmonização entre os participantes.

\section{Considerações finais}

Como verificou-se no itinerário histórico/jurídico realizado no presente texto, observa-se que o processo de integração na América Latina é intentado a partir do processo de formação dos Estados Nações a partir do processo de descolonização latino-americano. Os povos dessa região tinham em comum questões culturais, religiosas, étnicas, além do subdesenvolvimento econômico e social.

Como visto, Simon Bolívar se destacou entre aqueles que intentavam a integração dos povos sul-americanos. Em que pese não obter imediato êxito em seu ideal, deu um passo importante para a evolução do processo de integração que, até nos dias atuais, ainda não tenha atingido plena consolidação.

Ao longo dos séculos XIX e XX, foram várias as tentativas de integração entre as nações sul-americanas. Contudo, sempre houve dificuldades para atingir seu intento, devido aos interesses econômicos das nações desenvolvidas europeias, de modo especial, a Inglaterra, e por vezes pela influência dos EUA, que preferiam negociar individualmente com cada país, ao invés de fazê-lo com um bloco econômico forte.

No entanto, a partir das décadas de 80 e 90, com a redemocratização na América do Sul, após longo período de ditaduras militares, conseguiu-se avançar na política de integração na região pelo reestabelecimento da mútua confiança entre os Estados vizinhos.

O surgimento do MERCOSUL evidenciou que o processo democrático foi determinante para sua formação, oportunizando-se a cooperação entre Estados que se uniram a fim de possibilitar a melhoria das condições econômicas, sociais e políticas de sua população.

Com isso, restou evidenciado que a democracia perante os blocos, principalmente o MERCOSUL, é identificada como um princípio supremo, fundamental à estabilidade política, à paz e ao desenvolvimento dos países e dos processos de integração do continente americano, bem como para a 
proteção dos direitos humanos nas Américas, e nesse contexto é que surgiram as chamadas cláusulas democráticas no continente Latino-Americano, presentes em instrumentos jurídicos internacionais importantes, como: a OEA, o MERCOSUL e a UNASUL.

Entretanto, a questão preocupante é o fato que as cláusulas democráticas estão sendo elaboradas tecnicamente na forma de cláusulas gerais e indeterminadas, abrindo-se à possibilidade de interpretação discricionária do que seja um regime democrático, permitindo que, na aplicação da severa penalidade de suspensão de um Estado do bloco, possam esconder motivos de interesses dos mais diversos, muitas vezes azeitados pela dinâmica de políticas regionais, interesses econômicos individuais ou divergências ideológicas, principalmente quando há troca de governos na região.

Comparativamente com a União Europeia, vimos que a previsão de cláusula democrática, principalmente nos Tratado de Amsterdã e Lisboa, pouco se difere da cláusula democrática prevista para o MERCOSUL, no Protocolo de Ushuaia sobre Compromisso Democrático no MERCOSUL, Bolívia e Chile, pois em ambas não há uma definição do que seja democracia.

Desta feita, o presente trabalho buscou estabelecer uma reflexão acerca da democracia, como fundamento da integração no MERCOSUL, e a estipulação de cláusulas democráticas. Além disto, apontou a necessidade de estipulação de balizas caracterizadoras do compromisso democrático, definindo claramente elementos, pressupostos e extensão.

Assim, o desenvolvimento de cláusulas democráticas com uma definição clara do que se entende por democracia possibilitará aos países signatários dos tratados internacionais, no caso o Protocolo de Ushuaia, não serem surpreendidos com penalidades incorretas e injustas com base na discricionariedade de cláusulas gerais e indeterminadas, além do fato que prejudica a mútua confiança entre os participantes do bloco, afastando-se do objetivo da plena consolidação do MERCOSUL.

\section{Referências}

AMORIM, Celso. A Integração Sul-Americana. Diplomacia, Estratégia e Política. Projeto Raúl Prebisch n. 10 (outubro/dezembro 2009) - Brasília. 2009.

BONAVIDES, Paulo. Curso de direito: direito constitucional. 15. ed. São Paulo: Malheiros, 2004. 
. A Quinta Geração de Direitos Fundamentais. p. 93. Revista Direitos Fundamentais \& Justiça. n. 3, abr./jul. 2008.

BRAGATO, Fernanda Frizzo. Discursos Desumanizantes e Violação Seletiva de Direitos Humanos sob a Lógica da Colonialidade. Quaestio Iuris. vol.09, n. 04, Rio de Janeiro, p. 1812, 2016.

BRANT, Leonardo Nemer C. (coord.); REIS, Oswaldo Dehon Roque. As Origens do MERCOSUL, A Construção da Ordem Política no Cone Sul. Curitiba: Editora Juruá. 2012.

BRANDÃO, Antônio Salazar P.; PEREIRA, Lia Valls (org). MERCOSUL perspectivas da integração. Rio de Janeiro: Editora Fundação Getúlio Vargas. 1996.

BUGIATO, Caio Martins. Revista de Iniciação Científica da FFC, v. 7, n. 2, p. 126-139, 2007.

DATHEIN, Ricardo. MERCOSUL: antecedentes, origem e desempenho recente. Revista de Economia, Curitiba, Editora UFPR. v. 31, n. 1(29), p. 7-40, jan./jun. 2005.

DONGHI, Túlio Halperin. História da América Latina; tradução de Carlos Nelson Coutinho. Rio de Janeiro: Editora Paz e Terra. 1975.

FERREIRA, Carlos Serrano; VIEIRA, Wilson. A construção da nação na América Latina, um processo interrompido: bloqueios internos e externos. PLURAL, Revista do Programa de Pós-Graduação em Sociologia da USP, São Paulo, v.24.2, p.38-64, 2017.

FIGUEIREDO, Alexandre Ganan de Brites; BRAGA, Márcio Bobik. Passagens. Revista Internacional de História Política e Cultura Jurídica Rio de Janeiro, vol. 9, n. 2, p. 308-329, maio/ago. 2017.

FLORÊNCIO, Sérgio Abreu e Lima; ARAÚJO, Ernesto Henrique Fraga. MERCOSUL hoje. São Paulo: Editora Alfa-Omega, 1998.

FREIXO, Adriano; RISTOFF, Taís. Democracia e integração regional: a experiência do MERCOSUL. Agenda Social, Universidade Estadual do Norte Fluminense (UENF), v. 1, p. 32-47, 2008.

GOMES, Eduardo Biacchi; XAVIER, Fernando César Costa; SQUEFF, Tatiana de A. F. Rodrigues Cardoso. (Org.). Golpes de Estado na América Latina e a cláusula democrática. Curitiba: Editora Instituto Memória, 2016. 
MARQUES, Fabrício R.; CRUZ, Luís Rodolfo. Creuz/Marcelo Driusso Cadernos PROLAM/USP (Ano 9 - Vol. 2 - 2010).

MENDES, Ricardo Antonio Souza. Ditaduras civil-militares no Cone Sul e a Doutrina de Segurança Nacional - algumas considerações sobre a Historiografia, Revista Tempo e Argumento, Florianópolis, v. 5, n. 10, a. 2013.

PABST, Haroldo. MERCOSUL Direito da Integração. 1. ed. Rio de Janeiro: Editora Forense. 1997.

PEREIRA, Luciano Meneguetti. A Promoção e a Proteção da Democracia no Continente Americano: Reflexões Sobre as Organizações de Integração Regional e as Cláusulas Democráticas. In: GOMES, Eduardo Biacchi; XAVIER, Fernando César Costa; SQUEFF, Tatiana de A. F. Rodrigues Cardoso. (Org.). Golpes de Estado na América Latina e a cláusula democrática. Curitiba: Editora Instituto Memória, 2016.

RIBEIRO, Antônio Carlos; ANDRADE, Mayra Thaís Silva. A Construção da Democracia Regional no Processo de Integração Desenvolvido no MERCOSUL. Rev. Fac. Dir. Sul de Minas, Pouso Alegre, v. 31, n. 1: 9-34, jan./ jun. 2015.

RIBEIRO, Clarissa Correa Neto. DIZ, Jamile Bergamaschine Mata. A Situação do Paraguai no Contexto do MERCOSUL: A Integração Sul-Americana a Partir de Uma Concepção Democrática. Direito internacional I. 1. ed. Florianópolis: FUNJAB/CONPEDI, 2014.

SANT'ANNA, Sérgio Luiz Pinheiro. Democracia, Crise Política e os Fundamentos da Cláusula Democrática. In: SCHEIDT, Eduardo; JUAN, Luis Gutierrez San; ARAÚJO, Elian. Integração na América Latina: a História, a Economia e o Direito - vol. 2, Jundiaí: Paco Editorial. 2014.

SARTORI, Giovanni. A teoria da democracia revisitada. São Paulo: Ática, 1994.

SCOTTI, Luciana B.; Derecho de La Integración. 3. ed. Editorial Bdef Montevideo - Buenos Aires, 2018.

SOUZA, Nilson Araújo de. América Latina: as ondas da integração. Revista Oikos, Rio de Janeiro, Volume 11, n. 1, ano 2012, www.revistaoikos.org. TREIN, Franklin. MERCOSUL - Uma breve análise de suas origens à crise atual. Civitas - Revista de Ciências Sociais. Ano 1, noㅜ 1, outubro 2000. 
VELASCO, Ana Covarrubias. La cláusula democrática. Revista Mexicana de Política Exterior. Disponível em: <https://revistadigital.sre.gob.mx/ images/stories/numeros/n62-63/covarrubias.pdf>. Acesso em: 14 jul. 2018.

VIEIRA, Luciane Klein; JUNIOR, Alberto do Amaral. A Proteção Internacional do Consumidor no MERCOSUL. Revista de Direito do Consumidor. RDC. vol. 106 (Julho - Agosto 2016), 2016.

WASSERMAN, Claudia. História da América Latina: cinco séculos (temas e problemas). 3. ed. Porto Alegre: Editora da UFRGS, 2010.

ZANETTI, Augusto. O MERCOSUL - Dimensões do Processo de Integração na América do Sul. São Paulo: Editora Claridade, 2015.

\section{Normas consultadas}

http://www.planalto.gov.br/ccivil_03/decreto/1990-1994/d0350.htm. Acesso em: 09 jul. 2018.

http://www.mercosur.int/msweb/portal\%20intermediario/Normas/Tratado\%20e\%20Protocolos/1998_PROTOCOLO \%20DE\%20USHUAIA-Compromiso\%20democr\%C3\%A1 tico_port.pdf . Acesso em: 14 jul. 2018. http://www.oas.org/sap/peacefund/VirtualLibrary/CongressofLima1847/ Treaty/TratadoConfederacionPeruBoliviaChileEcuadorNuevaGranada.pdf. Acesso em: 14 jul. 2018.

http://www.sgt4.mercosur.int/es-es/Documents/Protocolo_de_Montevideo.pdf Acesso em: 14 jul. 2018.

http://www2.camara.leg.br/legin/fed/decleg/1991/decretolegislativo-226-12-dezembro-1991-358251-publicacaooriginal-1-pl.html Acesso em: 14 jul. 2018.

https://europa.eu/european- union/sites/europaeu/files/docs/body/treaty_of_amsterdam_pt.pdf Acesso em: 14 jul. 2018.

https://www.parlamento.pt/europa/Documents/Tratado_Versao_Consolidada.pdf. Acesso em: 14 jul. 2018.

Carlos Alberto Moraes - Analista Judiciário do Tribunal Regional Eleitoral de Santa Catarina. Mestre em Direito Público pela Universidade do Vale do Rio dos Sinos (Unisinos). Especialista em Direito Público pela Universidade do Vale do Itajaí (Univali). Professor de Direito Administrativo na Universidade do Alto Vale do Itajaí (Unidavi). 
